\title{
Angiotensin-converting enzyme 2 and angiotensin 1-7: novel therapeutic targets
}

\author{
Fan Jiang, Jianmin Yang, Yongtao Zhang, Mei Dong, Shuangxi Wang, Qunye Zhang, Fang Fang Liu, \\ Kai Zhang and Cheng Zhang
}

\begin{abstract}
The renin-angiotensin system (RAS) has pivotal roles in the regulation of normal physiology and the pathogenesis of cardiovascular disease. Angiotensin-converting enzyme (ACE) 2, and its product angiotensin 1-7, are thought to have counteracting effects against the adverse actions of other, better known and understood, members of the RAS. The physiological and pathological importance of ACE2 and angiotensin 1-7 in the cardiovascular system are not completely understood, but numerous experimental studies have indicated that these components have protective effects in the heart and blood vessels. Here, we provide an overview on the basic properties of ACE2 and angiotensin 1-7 and a summary of the evidence from experimental and clinical studies of various pathological conditions, such as hypertension, atherosclerosis, myocardial remodelling, heart failure, ischaemic stroke, and diabetes mellitus. ACE2mediated catabolism of angiotensin II is likely to have a major role in cardiovascular protection, whereas the relevant functions and signalling mechanisms of actions induced by angiotensin 1-7 have not been conclusively determined. The ACE2-angiotensin 1-7 pathway, however, might provide a useful therapeutic target for the treatment of cardiovascular disease, especially in patients with overactive RAS.
\end{abstract}

Jiang, F. et al. Nat. Rev. Cardiol. 11, 413-426 (2014); published online 29 April 2014; doi:10.1038/nrcardio.2014.59

\section{Introduction}

The importance of the renin-angiotensin system (RAS) in the regulation of normal physiology and pathogenesis of cardiovascular disease is well established. ${ }^{1-4}$ The best-known components of the RAS include angiotensinogen, angiotensin I and II, and the peptidases renin and angiotensin-converting enzyme (ACE). Renin is the ratelimiting enzyme in the RAS, whereas angiotensin II is the major effector molecule, which exerts its biological actions via the type- 1 angiotensin II (AT1) and type-2 angiotensin II (AT2) receptors. Angiotensin II is generated in the circulation and within tissues (local RAS). ${ }^{1,3,5,6}$ RAS is implicated in the pathogenesis of various cardiovascular disorders, including hypertension, atherosclerosis, myocardial infarction, pathological cardiac remodelling, heart failure, and metabolic syndrome..$^{1,2,4}$ ACE2 and its product angiotensin 1-7 were identified more recently than the aforementioned components of this system, and are thought to have counteracting effects against the adverse actions of these other RAS components (Figure 1), ${ }^{7}$ although their physiological and pathophysiological roles are incompletely understood. Findings from numerous experimental studies have suggested notable protective effects in the heart, blood vessels, kidney, and central nervous system. ACE2 and angiotensin 1-7 might, therefore, represent new therapeutic targets for cardiovascular disease. ${ }^{7}$ In this Review, we summarize the evidence from experimental and

Competing interests

The authors declare no competing interests. clinical studies of the effects of ACE2 and angiotensin 1-7 in various pathological cardiovascular conditions.

\section{Properties of ACE2}

Biochemical characteristics

ACE2 (also known as ACE-related carboxypeptidase, angiotensin-converting enzyme homologue, or ACEH) is a monocarboxypeptidase that is mainly expressed in vascular endothelial cells and the renal tubular epithelium. ${ }^{8}$ The gene for ACE2 was cloned in 2000 by two independent groups as a homologue of human ACE. ${ }^{8,9}$ The ACE2 protein is an 805 amino-acid type-I transmembrane protein that contains an extracellular (ecto) domain (amino acids 18-739), a transmembrane region (amino acids 740-768), and an intracellular tail. The extracellular part of ACE2 (Figure 2) contains the catalytic domain (amino acids 147-555), which has a substrate binding region (amino acids 273-345) and a typical HEMGH metalloproteinase zinc-binding site (amino acids 374-378). ${ }^{8,10-12,13}$ The C-terminal part of ACE2 (614-805) is homologous ( $48 \%$ identity) to a transporter protein known as collectrin. ${ }^{11,14}$ The catalytic domain of ACE2 is $42 \%$ identical to that of ACE. ${ }^{8}$

The peptidase activity of ACE2 is dependent on the $\mathrm{C}$-terminus sequence of the substrate (sequence specificity). ACE2 substrates generally have a hydrophobic or basic residue at the C-terminal end, preceded by a Pro-X-Pro motif, where either one of the two proline residues is sufficient to allow ACE2-dependent hydrolysis. ${ }^{15}$ In this circumstance, ACE2 displays potent peptidase 


\section{REVIEWS}

\section{Key points}

- Angiotensin-converting enzyme (ACE) 2 and its product angiotensin 1-7 are thought to have effects that counteract the adverse actions of other, better-known renin-angiotensin system (RAS) components

- Numerous experimental studies have suggested that ACE2 and angiotensin 1-7 have notable protective effects in the heart and blood vessels

- ACE2-mediated catabolism of angiotensin II is likely to have a major role in cardiovascular protection, whereas the functional importance and signalling mechanisms of angiotensin-1-7-induced actions remain unclear

- New pharmacological interventions targeting ACE2 are expected to be useful in clinical treatment of cardiovascular disease, especially those associated with overactivation of the conventional RAS

- More studies, especially randomized controlled clinical trials, are needed to clearly delineate the benefits of therapies targeting angiotensin 1-7 actions

activity to angiotensin II (Pro-Phe), angiotensin I (ProPhe-His-Leu), and des- Arg $^{9}$ bradykinin (Ser-Pro-Phe), but shows no activity towards angiotensin 1-9, angiotensin $1-7$, or bradykinin. ${ }^{16}$ ACE2 can also hydrolyse other bioactive peptides, such as apelin-13, $\beta$-casomorphin, dynorphin A 1-13, and ghrelin. ${ }^{16}$ The most-important active product of ACE2 is angiotensin 1-7, which can be primarily generated via two routes. First, ACE2 can directly hydrolyse angiotensin II to yield angiotensin 1-7; second, ACE2 can convert angiotensin I to angiotensin 1-9, which is then cleaved by either neutral endopeptidase (NEP) or ACE to yield angiotensin 1-7.12,17,18 In addition, angiotensin 1-7 can be produced by prolyl carboxypeptidase from angiotensin II or by NEP directly from angiotensin $\mathrm{I}^{18}$ The biological functions of angiotensin 1-9 are poorly understood, although important effects in the cardiovascular system have been purported. ${ }^{19,20}$ The affinity of ACE2 to angiotensin II $\left(\mathrm{K}_{\mathrm{m}}=2.0 \mu \mathrm{mol} / \mathrm{l}\right.$, which represents the concentration of substrate required for the enzyme to achieve half maximum catalytic velocity; that is, the higher the $\mathrm{K}_{\mathrm{m}}$ value, the lower the affinity) is higher than to angiotensin $\mathrm{I}\left(\mathrm{K}_{\mathrm{m}}=6.9 \mu \mathrm{mol} / \mathrm{l}\right)$. The ACE2 catalytic efficiency for angiotensin II is $>300$ times that for angiotensin $\mathrm{I} .{ }^{16}$ The angiotensin I-ACE-angiotensin IIACE2-angiotensin 1-7 pathway (Figure 1) ought, therefore, to have a predominant role in the production of angiotensin 1-7 in vivo.

The membrane-bound ectodomain of ACE2 can be cleaved by the metalloproteinase ADAM17, which releases a soluble form of ACE2 (Figure 1). ${ }^{21,22}$ By use of serial deletion constructs of ACE2, Iwata and colleagues identified a juxtamembrane region (amino acids $720-$ 729) that is essential for ADAM17-mediated ectodomain

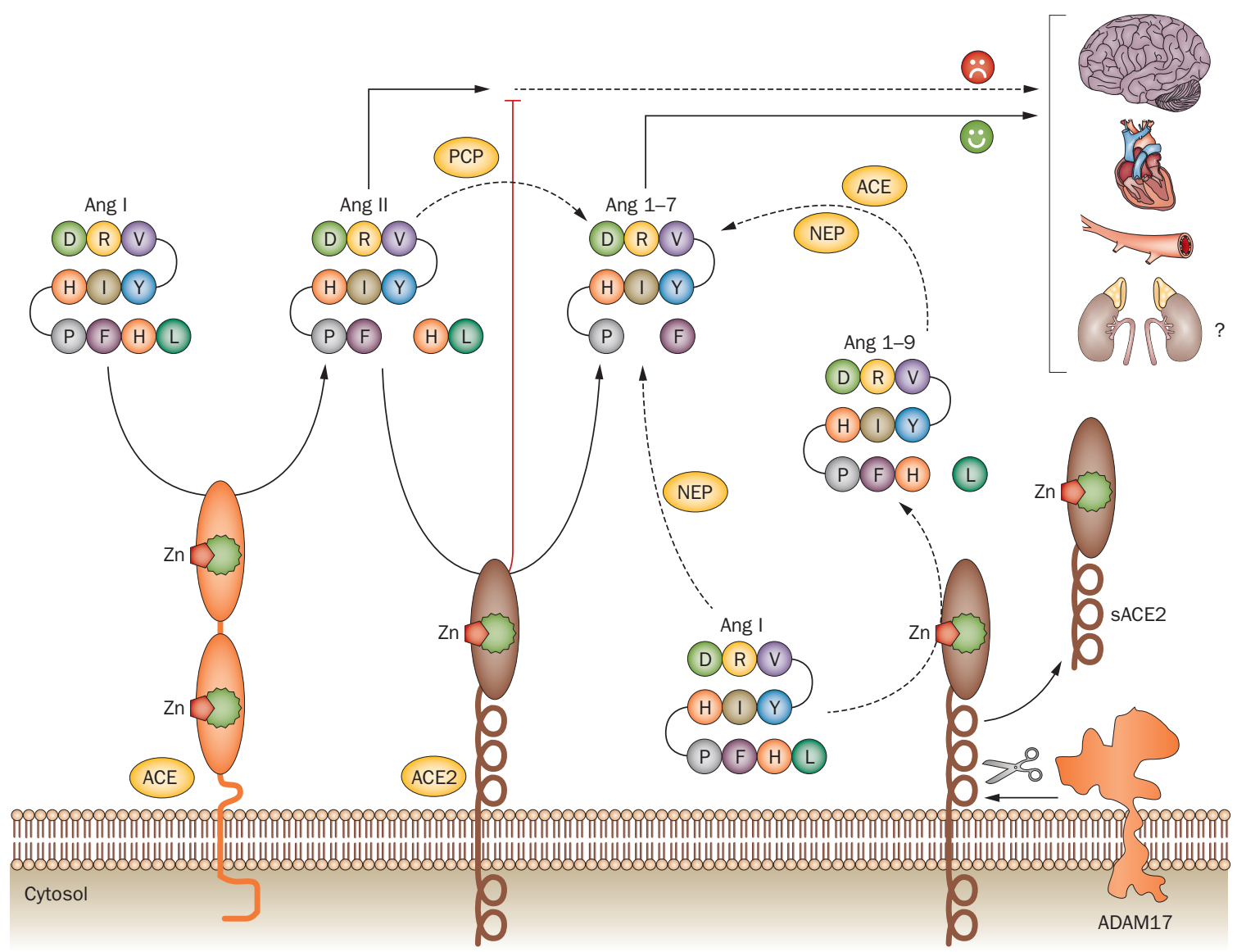

Figure 1 | Overview of the ACE2-Ang 1-7 pathway. ACE2 converts Ang II to Ang 1-7. ACE2 can also convert Ang I to Ang 1-9, which is then cleaved by either NEP or ACE to yield Ang 1-7. The membrane-bound ACE2 can be cleaved by the metalloproteinase ADAM17, forming a soluble form of ACE2. The physiological relevance of soluble ACE2 is not fully understood. Abbreviations: ACE, angiotensin-converting enzyme; Ang, angiotensin; NEP, neutral endopeptidase; PCP, prolyl carboxypeptidase. 
shedding. ${ }^{23}$ The physiological relevance of soluble ACE2 is not fully understood. Its activity in plasma is raised in patients with chronic heart failure ${ }^{23}$ and is associated with increased cardiac dysfunction and poor clinical outcomes. ${ }^{24}$ Moreover, soluble ACE2 activity is raised after myocardial infarction, which has been associated with an increased incidence of subsequent adverse left ventricular remodelling. ${ }^{25}$ Findings from one study suggested that angiotensin II promotes ACE2 shedding by increasing ADAM17 activity in the myocardium. This action represents a positive feedback mechanism by which angiotensin II facilitates myocardial injury. ${ }^{26}$

\section{Pharmacological activators and inhibitors}

Several compounds are known to affect ACE2 activity. MLN-4760 is a specific and potent ACE2 inhibitor with a half maximum inhibitory concentration $\left(\mathrm{IC}_{50}\right)$ of $0.4 \mathrm{nmol} / \mathrm{l} .{ }^{27} \mathrm{X}$-ray diffraction studies have revealed that the catalytic domain of ACE2 contains two subdomains linked by an $\alpha$-helix hinge region, which forms a long and deep cleft. MLN-4760 binds to both of the subdomains (Figure 2) and causes the hinge to flex, which shrinks the cleft and prevents substrate binding. ${ }^{28}$ ACE2 inhibition in vivo by MLN-4760 aggravated glomerular injury in a model of type 1 diabetes mellitus, ${ }^{29}$ and exacerbated cardiac hypertrophy and fibrosis in transgenic hypertensive rats. ${ }^{30}$

DX600 is a peptide inhibitor of ACE2 with a high affinity $\left(\mathrm{K}_{d}=10.8 \mathrm{nmol} / \mathrm{l}\right.$; this value is the equilibrated concentration required to achieve $50 \%$ occupancy of the receptors in radioligand binding assays; that is, the higher the $\mathrm{K}_{d}$ value, the lower the affinity) and high efficacy $\left(\mathrm{IC}_{50}=10.1 \mathrm{nmol} / \mathrm{l}\right)$, but has no obvious inhibitory effect toward ACE. ${ }^{31}$ In in vitro and in vivo experiments, DX600 has shown antagonistic effects on ACE2-mediated actions. ${ }^{32,33}$ Kinetic analyses have revealed that DX600 exhibits a mixed competitive and noncompetitive type of inhibition, which indicates that this peptide might act as a partial allosteric modulator of ACE2; this mode of action is analogous to that of some ACE inhibitors, such as captopril. ${ }^{31}$ Several studies reported that DX600 displayed different efficacy of inhibition for human and rodent ACE2. ${ }^{34,35}$

Given the potential protective roles of ACE2 in the cardiovascular system, identification of novel ACE2 activators is an important avenue for drug discovery. Two small-molecule ACE2 enhancers, xanthenone and resorcinolnaphthalein, have been discovered. ${ }^{36}$ In vitro, these compounds enhanced ACE2 activity by around twofold at concentrations of $100 \mu \mathrm{mol} / \mathrm{l}$, but showed no effects on ACE activity. The pharmacological effects of xanthenone were further explored in vivo in healthy, normal rats and spontaneously hypertensive rats (SHRs), and showed remarkable hypotensive and cardiac protective actions..$^{36,37}$ Potent antithrombotic actions were reported for xanthenone in a rat model of venous thrombosis, whereas DX600 led to opposite effects. ${ }^{33}$ These beneficial effects should, however, be interpreted with caution, because xanthenone can increase ACE2 expression. ${ }^{37}$ Indeed, the specificity of xanthenone for ACE2 has been questioned. ${ }^{38}$

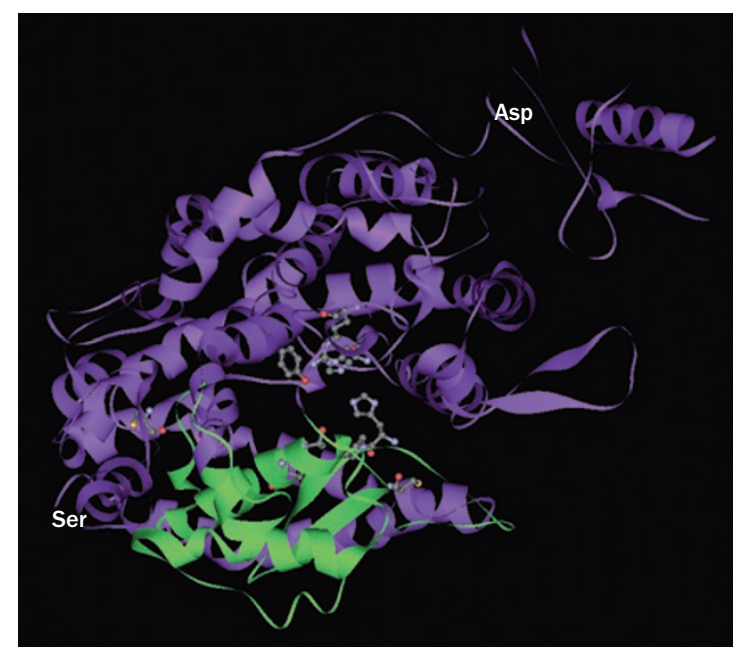

Figure 2 | Structure of the extracellular domain (from Ser19 to Asp615) of human ACE2. In this image, the extracellular domain is arbitrarily divided into two subdomains (shown in green and purple), forming a deep cleft that is proposed to be the active site for substrate binding and catalysis. The catalytic domain (amino acids 147-555) has a substrate binding region (amino acids 273-345) and a typical HEMGH metalloproteinase zinc-binding site (amino acids 374378). The regions shown in ball-and-stick figuration are proposed binding sites for the ACE2 inhibitor MLN-4760. Abbreviation: ACE2, angiotensin-converting enzyme 2. Amino acid sequence annotations are derived from Towler, P. et al. J. Biol. Chem. 279, 17996-18007 (2004). ${ }^{28}$

\section{Properties of angiotensin 1-7}

\section{Biochemical characteristics}

In addition to ACE2-dependent routes, angiotensin 1-7 can be generated directly from angiotensin I by prolyl endopeptidase and NEP. ${ }^{18}$ The heart, brain, and kidney are major sources of angiotensin 1-7 production. ${ }^{17}$ In the human coronary circulation, NEP seems to have a more-prominent role in angiotensin 1-7 production than ACE2. ${ }^{39}$ Pharmacokinetic experiments have determined that, in humans, angiotensin 1-7 has a short half-life of $\sim 0.5 \mathrm{~h} .{ }^{40}$ Following subcutaneous injection, the peptide is quickly available in the blood and reaches its peak plasma concentration at $\sim 1 \mathrm{~h} .{ }^{40}$ In rats, the plasma halflife of angiotensin 1-7 is only $9 \mathrm{~s} .{ }^{41}$ Angiotensin $1-7$ is metabolized mainly by ACE in the lungs. ${ }^{42}$ In addition, aminopeptidase and NEP can degrade angiotensin 1-7 into peptide segments. ${ }^{42}$

Angiotensin 1-7 has broad effects in the cardiovascular system, including vasodilatation; myocardial protection; antiarrhythmic, antihypertensive, and positive inotropic effects; and inhibition of pathological cardiac remodelling. ${ }^{18,43,44}$ In addition, angiotensin $1-7$ is thought to have favourable effects on metabolism by lessening insulin resistance. ${ }^{45-47}$ Although most effects are protective, some seem to be variable. For example, effects on arrhythmia might be biphasic, with high concentrations of angiotensin 1-7 promoting cardiac arrhythmias and low concentrations having protective effects. ${ }^{4-50}$ Similarly, some experimental findings suggest that the 
biological functions of angiotensin 1-7 in the kidney might be beneficial (diuretic or natriuretic, antifibrotic, and antiproliferative), whereas other findings suggest they are detrimental (antidiuretic, proinflammatory, and profibrotic). . $^{18,44}$

Although the biological actions of angiotensin 1-7 are well described, the signalling mechanisms are still poorly understood. Treatment with angiotensin 1-7 activates the phosphatidylinositol-3-kinase-Akt pathway in vitro ${ }^{51-54}$ and in vivo. ${ }^{45,55}$ This action could at least partly explain the beneficial effects of angiotensin 1-7 on blood vessel functions and metabolism, given the pivotal roles of Akt in promoting endothelial nitric oxide synthase function and insulin signalling..$^{18}$ By contrast, angiotensin $1-7$ has inhibitory effects on activated mitogen-activated protein kinase (MAPK) pathways in endothelial cells, ${ }^{56}$ smoothmuscle cells,${ }^{57,58}$ cardiac myocytes, ${ }^{59}$ and renal proximal tubular cells. ${ }^{60}$ In these cells, angiotensin II induces oxidative, hypertrophic, and proliferative responses by activating MAPKs and, therefore, angiotensin 1-7 might counter-regulate these effects. The effects of angiotensin 1-7 on MAPKs, however, are highly cell specific; in some types of cells, angiotensin 1-7 augments basal or angiotensin-II-induced MAPK activation. ${ }^{61-63}$ Smoothmuscle depolarization via angiotensin 1-7-induced opening of potassium channels has been demonstrated, and seems to be dependent on activation of the cAMPcAMP-dependent protein kinase (PKA) pathway. ${ }^{64}$

\section{Receptors and their agonists and antagonists}

Early radioligand-binding studies indicated that angiotensin 1-7 could bind to the AT1 receptor in the brain and kidney, ${ }^{65,66}$ although in a study that used a morehomogenous assay system, virtually no binding was observed in HEK293 cells stably expressing AT1 receptors. ${ }^{67}$ Angiotensin 1-7 binds to the AT2 receptor with a moderate affinity (five times lower than that for angiotensin II) ${ }^{67}{ }^{6 n}$ vitro ${ }^{68}$ and in $v i v o^{69}$ studies have demonstrated that certain biological effects of angiotensin 1-7 can be attenuated by use of the AT2 receptor antagonist PD123319 and, therefore, angiotensin 1-7 binding to AT2 receptors is functionally relevant.

The Mas protein, which was originally cloned as an oncogene product, ${ }^{70}$ is a seven-transmembrane G-protein-coupled receptor with a high affinity for angiotensin $1-7\left(\mathrm{~K}_{d}=0.83 \mathrm{nmol} / \mathrm{l}\right){ }^{71}$ The gene for this protein, MAS1, is mainly expressed in the brain, testis, kidney, and heart. ${ }^{72-76}$ The expression level of Mas is dynamically regulated by physiological and pathological stimuli in the heart. ${ }^{77}$ Mas expression is also observed in vascular endothelial cells. ${ }^{53,73,78}$ Expression of Mas remains to be confirmed in vascular smooth-muscle cells, although angiotensin 1-7-induced effects have been readily observed in these cells in various functional experiments. ${ }^{58,79,80}$ Mas1-knockout animals show cardiovascular-related phenotypes, including myocardial contractile dysfunction, cardiac fibrosis, hypertension, endothelial dysfunction, renal fibrosis, glomerular dysfunction, insulin resistance, and dyslipidaemia. ${ }^{75,81-83}$ However, in two studies in which different models of hypertension (the two-kidney, one-clip model and hypertension induced in response to high salt ingestion) were assessed, Mas deficiency had opposite effects on blood pressure. ${ }^{84,85}$

Functional studies have suggested that most cardiovascular effects of angiotensin 1-7 are likely to be mediated by Mas. ${ }^{18,86-88}$ The precise angiotensin 1-7-Mas signalling mechanisms in the context of cardiovascular physiology have not, however, been firmly established. First, MAS1 is an oncogene, and activation of Mas signalling induces cell transformation via the small GTPase p21-Rac1 ${ }^{89}$ This effect is not reproduced by angiotensin 1-7. Rather, it has some antitumorigenic effects. ${ }^{90,91}$ Second, Mas is constitutively coupled to $\mathrm{G} \alpha_{q^{\prime 11}}$ and downstream phospholipase C-protein kinase C signalling. ${ }^{92,93}$ Evidence indicates, however, that angiotensin 1-7 does not stimulate $\mathrm{G} \alpha$ signalling in Mas-expressing cells. ${ }^{93}$ Moreover, ectopic expression of Mas induces an increase in the intracellular concentration of $\mathrm{Ca}^{2+}$, whereas angiotensin 1-7 treatment does not raise intracellular concentrations of $\mathrm{Ca}^{2+} \cdot{ }^{93-95}$ Third, the mechanistic link between Mas and the Akt pathway, which has been implicated in the cardioprotective actions of angiotensin $1-7$, is still missing.

In many circumstances, the effects of angiotensin 1-7 are antagonistic to those induced by angiotensin II in the cardiovascular system, ${ }^{18,56,58,96}$ but the underlying signalling mechanisms remain to be defined. Mas binds directly to the AT1 receptor, but the interaction is unlikely to have a role in mediating angiotensin 1-7 effects, since administration of angiotensin 1-7 has no effects on this complex. ${ }^{97}$ Despite the discovery of binding, Mas is still classified as a class A orphan receptor under the latest International Union of Basic and Clinical Pharmacology classification..$^{98}$

The widely used Mas antagonist (D-Ala $)$-angiotensin(1-7) is an angiotensin 1-7 analogue with the last proline residue substituted with D-Ala. ${ }^{99}$ This agent is water soluble. Radioligand-binding experiments show that (D-Ala ${ }^{7}$-angiotensin-(1-7) has a high efficacy in Mas inhibition $\left(\mathrm{IC}_{50}\right.$ for angiotensin $1-7$ binding $\left.=0.3 \mathrm{nmol} / \mathrm{l}\right){ }^{.1} \mathrm{By}$ contrast, the binding affinity of $\left(\mathrm{D}-\mathrm{Ala}^{7}\right)$-angiotensin-(1-7) to the AT1 and AT2 receptors is negligible. ${ }^{67,99} \mathrm{~A}$ similar peptide Mas antagonist is (D-Pro ${ }^{7}$-angiotensin-(1-7). The pharmacological properties of this agent have not been fully characterized, but at $10 \mu \mathrm{mol} / \mathrm{l}$ it exhibits similar effects to $\left(\mathrm{D}-\mathrm{Ala}^{7}\right)$-angiotensin-(1-7) in competing for angiotensin 1-7 binding, and showed weak affinities for the AT1 and AT2 receptors. ${ }^{100}$ Currently, no specific nonpeptide Mas antagonist is available.

AVE 0991 is a small-molecule agonist with high affinity and selectivity for Mas that competes for specific binding of angiotensin 1-7. It has an $\mathrm{IC}_{50}$ of $\sim 10^{-8} \mathrm{~mol} / \mathrm{l}$, and virtually no affinity to the AT1 or AT2 receptors. ${ }^{67,101,102}$ The maximum stimulating effect of AVE 0991 on release of endothelial nitric oxide is equivalent to that of angiotensin $1-7 . .^{101}$

CGEN-856S is a 24 amino acid peptide with no obvious homology to angiotensin fragments or other known endogenous GPCR ligands. ${ }^{103}$ CGEN-856S at $0.1 \mu \mathrm{mol} / \mathrm{l}$ 
Table 1 | Experimental findings for the effects of ACE2 and Ang 1-7 on BP

\begin{tabular}{|c|c|c|c|}
\hline Animal models & Interventions & BP effect & References \\
\hline \multicolumn{4}{|l|}{ Effects of ACE2 } \\
\hline $\begin{array}{l}\text { Hypertension induced } \\
\text { by Ang II in mice }\end{array}$ & Ace2 gene deletion & $\uparrow$ & 104 \\
\hline $\begin{array}{l}\text { SHR and hypertension } \\
\text { induced by Ang II in rats }\end{array}$ & Ace2 gene transfer in CNS & $\downarrow$ & 105,106 \\
\hline $\begin{array}{l}\text { Hypertension induced } \\
\text { by Ang II in mice }\end{array}$ & $\begin{array}{l}\text { Ace } 2 \text { neuron-specific gene } \\
\text { transfer in CNS }\end{array}$ & $\downarrow$ & 107,108 \\
\hline Stroke-prone SHRs & $\begin{array}{l}\text { Vascular smooth-muscle-cell- } \\
\text { specific Ace } 2 \text { gene transfer }\end{array}$ & $\downarrow$ & 109 \\
\hline $\begin{array}{l}\text { Hypertension induced } \\
\text { by Ang II in mice, SHRs }\end{array}$ & $\begin{array}{l}\text { Systemic infusion of human } \\
\text { or murine recombinant ACE2 }\end{array}$ & $\downarrow$ & $\begin{array}{l}35,110 \\
111\end{array}$ \\
\hline SHRs & $\begin{array}{l}\text { Systemic infusion of an } \\
\text { ACE2 activator }\end{array}$ & $\downarrow$ & 36 \\
\hline \multicolumn{4}{|l|}{ Effects of angiotensin 1-7 } \\
\hline Healthy, normal rats & Ang 1-7 infusion in CNS & Null & 113 \\
\hline $\begin{array}{l}\text { Rats with normal blood } \\
\text { pressure and SHRs }\end{array}$ & Ang 1-7 infusion in CNS & $\uparrow$ & $\begin{array}{l}99,100 \\
126\end{array}$ \\
\hline $\begin{array}{l}\text { Hypertension induced } \\
\text { by Ang II in mice }\end{array}$ & $\begin{array}{l}\text { Systemic infusion } \\
\text { with Ang 1-7 }\end{array}$ & Null & 110 \\
\hline $\begin{array}{l}\text { Healthy, normal rats. } \\
\text { SHR, RHRs }\end{array}$ & $\begin{array}{l}\text { Systemic infusion } \\
\text { with Ang 1-7 }\end{array}$ & Null & $112-114$ \\
\hline $\begin{array}{l}\text { Healthy, normal rats, } \\
\text { SHRs, RHRs }\end{array}$ & $\begin{array}{l}\text { Systemic infusion } \\
\text { with Ang 1-7 }\end{array}$ & $\downarrow^{*}$ & 112,116 \\
\hline $\begin{array}{l}\text { Dahl salt-sensitive } \\
\text { rats, SHRs }\end{array}$ & $\begin{array}{l}\text { Systemic infusion } \\
\text { with Ang 1-7 }\end{array}$ & $\downarrow$ & $\begin{array}{l}115,117 \\
118\end{array}$ \\
\hline $\begin{array}{l}\text { DOCA-salt } \\
\text { hypertensive rats }\end{array}$ & $\begin{array}{l}\text { Systemic infusion } \\
\text { with Ang 1-7 }\end{array}$ & Null & 119 \\
\hline $\begin{array}{l}\text { DOCA and aldosterone } \\
\text { salt-hypertensive rats }\end{array}$ & Ang 1-7 infusion in CNS & $\downarrow$ & 124,125 \\
\hline $2 \mathrm{~K} 1 \mathrm{C}$ hypertensive rats & $\begin{array}{l}\text { Systemic infusion } \\
\text { with Ang 1-7 }\end{array}$ & Null ${ }^{\ddagger}$ & 120,121 \\
\hline $\begin{array}{l}\text { Subtotal-nephrectomy- } \\
\text { induced hypertension } \\
\text { in rats }\end{array}$ & $\begin{array}{l}\text { Systemic infusion } \\
\text { with Ang 1-7 }\end{array}$ & $\uparrow$ & 122 \\
\hline SHRs & $\begin{array}{l}\text { Infusion of monoclonal } \\
\text { antibody to Ang 1-7 }\end{array}$ & $\uparrow$ & 130 \\
\hline $\begin{array}{l}\text { Rats with normal blood } \\
\text { pressure and SHRs }\end{array}$ & $\begin{array}{l}\text { Systemic infusion } \\
\text { with (D-Ala }) \text {-Ang-(1-7) }\end{array}$ & Null & 128 \\
\hline $2 \mathrm{~K} 1 \mathrm{C}$ hypertensive rats & $\begin{array}{l}\text { Systemic infusion } \\
\text { with (D-Ala }) \text {-Ang-(1-7) }\end{array}$ & $\uparrow$ & 113 \\
\hline $\begin{array}{l}\text { Aldosterone salt- } \\
\text { hypertensive rats }\end{array}$ & $\begin{array}{l}\left.\text { (D-Ala }{ }^{7}\right) \text {-Ang-(1-7) infusion } \\
\text { in CNS }\end{array}$ & $\uparrow$ & 125 \\
\hline
\end{tabular}

and $1.0 \mu \mathrm{mol} / \mathrm{l}$ is equally as potent as angiotensin $1-7$ for Mas receptor binding. This agent has no binding activity for the AT1 receptor, but it shows a moderate binding affinity for the AT2 receptor $\left(\mathrm{IC}_{50} \sim 5 \mu \mathrm{mol} / \mathrm{l}\right) .{ }^{103}$

\section{Blood-pressure regulation}

ACE2 seems to have beneficial effects on the regulation of blood pressure (Table 1; Figure 3). ACE2-deficient C57BL/ 6 mice have raised basal blood pressure, with notable amplifications of angiotensin-II-induced hypertension, and have increased accumulation of angiotensin II in plasma and the kidney after angiotensin II infusion. ${ }^{104}$ Gain-of-function experiments in SHRs indicated that ACE2 expression in the central nervous system is associated with substantially decreased blood pressure. For example, overexpression of human ACE2 in the rostral ventrolateral medulla produced long-term hypotensive effects in SHRs. ${ }^{105}$ Similarly, overexpression of ACE2 in the paraventricular nucleus ameliorated hypertension induced by angiotensin II in healthy, normal rats. ${ }^{106}$ Moreover, pan-neuronal expression of ACE2 in the brain and delivery of ACE2-expressing adenoviruses into the cerebral ventricle have attenuated high blood pressure and improved baroreflex dysfunction induced by angiotensin II. ${ }^{107,108}$ In addition to these central actions, targeted expression of human ACE2 in vascular smooth muscle cells decreases blood pressure in stroke-prone SHRs. ${ }^{109}$

Pharmacological intervention studies have revealed similar beneficial effects of ACE2 on high blood pressure. Systemic administration of human recombinant ACE2 counteracted pressor effects induced by angiotensin II, which was associated with accelerated clearance of circulating angiotensin II. ${ }^{110,111}$ Moreover, in SHRs, chronic ACE2 treatment resulted in a sustained decrease in blood pressure. ${ }^{111}$ Murine recombinant ACE2 has similar antihypertensive effects to human ACE2 in hypertension induced by angiotensin II. ${ }^{35}$ Likewise, chronic infusion of the ACE2-activating compound xanthenone slightly decreases blood pressure in SHRs. ${ }^{36}$

In contrast to the reported protective effects of ACE2 in experimental hypertension, studies with angiotensin 1-7 have yielded rather heterogeneous results (Table 1). Most of the studies have shown that acute systemic infusion of angiotensin 1-7, in either rats with normal blood pressure or those with hypertension due to various aetiologies, does not change blood pressure. ${ }^{112-114}$ Decreases in mean blood pressure in Dahl salt-sensitive rats, however, have been reported. ${ }^{115}$ In anaesthetized mice, bolus administration of angiotensin 1-7 showed no effect on angiotensin-II-induced elevation in blood pressure or on blood-pressure recovery after injected angiotensin II was stopped. ${ }^{110}$ In healthy, normal rats, acute infusion of angiotensin 1-7 led to an enhancement of the hypotensive effects of bradykinin. ${ }^{112,116}$ Chronic treatment with angiotensin 1-7 was associated with transient or sustained reductions in blood pressure in various hypertensive models, including SHRs and Dahl salt-sensitive rats, ${ }^{117,118}$ but not in deoxycorticosterone-acetate (DOCA) salt-treated rats. ${ }^{119}$ Results in the two-kidney one-clip model of hypertension in rats have been inconsistent. ${ }^{120,121}$ Moreover, chronic angiotensin 1-7 treatment has been observed to further increase blood pressure in rats with hypertension induced by subtotal nephrectomy. ${ }^{122}$

Administration of angiotensin 1-7 into the central nervous system of rats has induced null, hypertensive, and hypotensive effects. Intracerebroventricular infusion of angiotensin 1-7 showed no effects in rats with normal blood pressure, ${ }^{113,123}$ and lowered blood pressure in DOCA and aldosterone salt-hypertensive rats. ${ }^{124,125}$ 


\section{REVIEWS}

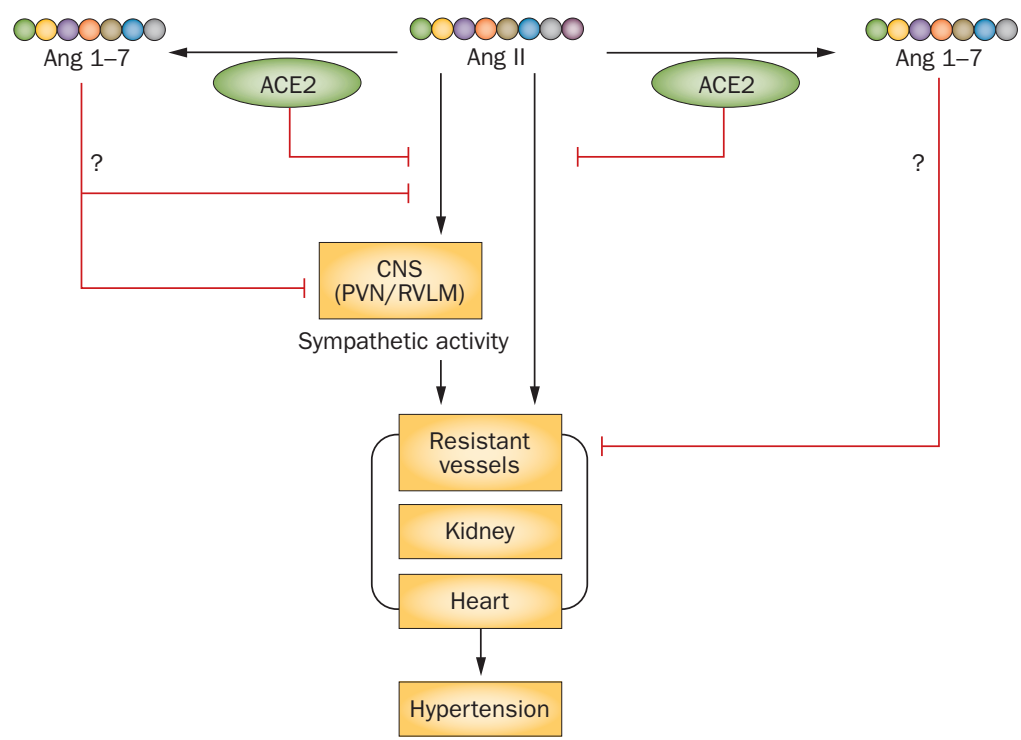

Figure 3 | Potential effects of ACE2 and Ang 1-7 on blood-pressure regulation. ACE2 is known to cause reductions in blood pressure, whereas various experimental evidence has indicated no effects, hypotensive effects, and hypertensive effects of Ang 1-7. Abbreviations: ACE2, angiotensin-converting enzyme 2; Ang, angiotensin; CNS, central nervous system; PVN, paraventricular nucleus, RVLM, rostral ventrolateral medulla.

Conversely, injection of angiotensin 1-7 into the rostral ventrolateral medulla triggered an increase in blood pressure in rats with normal blood pressure and in SHRs. ${ }^{99,100,126}$

In anaesthetized mice, acute treatment with (D-Ala $\left.{ }^{7}\right)$ angiotensin-(1-7) showed no effect on basal or angiotensin-II-induced systolic hypertension. ${ }^{110}$ Acute central administration of (D-Ala $\left.{ }^{7}\right)$-angiotensin-(1-7) does not change mean arterial blood pressure ${ }^{127}$ and chronic treatment does not modify the blood pressure ${ }^{128}$ in rats with normal blood pressure or SHRs. (D-Ala ${ }^{7}$-angiotensin-(1-7) given centrally or systemically, however, antagonizes the hypotensive actions of ACE2 in transgenic mice ${ }^{108}$ and worsens hypertension, baroreflex dysfunction, or both in various models. ${ }^{120,125,129}$ Acute infusion of a monoclonal antibody to angiotensin 1-7 in SHRs notably raised blood pressure. ${ }^{130}$

In humans, infusion of angiotensin 1-7 induced notable vasodilator effects in control individuals with normal blood pressure and in patients with hypertension. ${ }^{131}$ Yet, in another study, acute infusion of angiotensin 1-7 did not change the blood pressure in individuals with normal blood pressure. ${ }^{132}$

Taken together, these results suggest that ACE2 has potential blood-pressure-lowering effects via multiple mechanisms, among which catabolism of angiotensin II is likely to be essential (Figure 3). By contrast, the functional importance of ACE2-dependent angiotensin 1-7 production remains to be confirmed.

\section{Atherosclerosis}

ACE2 is expressed in atherosclerotic lesions in animal and human vessels. ${ }^{133-135}$ The role of ACE2 in atherogenesis (Figure 4) has been investigated with use of various in vivo models. ${ }^{136}$ Systemic overexpression of ACE2 suppressed atherogenesis in apolipoprotein-E-knockout mice. ${ }^{137}$ A similar antiatherosclerotic effect of ACE2 was seen in rabbits fed with a high-cholesterol diet. ${ }^{138}$ ACE2 overexpression also stabilized the atherosclerotic plaques via inhibition of inflammation and production of matrix metalloproteinases; this effect was reversed by (D-Ala ${ }^{7}$ angiotensin-(1-7). ${ }^{139}$ Conversely, loss-of-function mutations in Ace 2 promoted plaque accumulation with increased expression of inflammatory adhesion molecules and cytokines. ${ }^{140-142}$

Similar to ACE2, angiotensin 1-7 has beneficial effects in experimental atherosclerosis (Figure 4). Long-term treatment with angiotensin 1-7 in apolipoprotein-Eknockout mice prevented progression of atherosclerotic lesions and improved endothelial function of nitric oxide. ${ }^{143}$ These effects seemed to involve both Mas and the AT2 receptor. Systemic administration of angiotensin 1-7 inhibited atherosclerotic lesion formation and enhanced plaque stability in mice in a dose-dependent manner. These effects were associated with decreased proliferation and migration of vascular smooth muscle cells, and decreased macrophage release of inflammatory cytokines. ${ }^{144}$ Activation of the angiotensin 1-7 receptor with AVE 0991 also inhibited atherogenesis in apolipoprotein-E-knockout mice. ${ }^{145,146}$ The atheroprotective actions of angiotensin 1-7 could be related to its inhibitory effects on vascular inflammation and smooth-muscle-cell proliferation and migration, probably via Mas-mediated suppression of the nuclear factor $\kappa \mathrm{B}$ or MAPK pathways, or both. ${ }^{58,144,147}$ Although $\left(\mathrm{D}-\mathrm{Ala}^{7}\right)$-angiotensin-(1-7) alone does not modulate early atherogenesis, it seems to aggravate destabilization of atherosclerotic plaques. ${ }^{143,144}$

\section{Cardiac remodelling and heart failure}

ACE2 was originally cloned as a heart-failure-associated gene from the heart tissue of a patient with idiopathic dilated cardiomyopathy, ${ }^{8}$ but studies have not unequivocally confirmed that cardiac expression is changed in human heart failure. ${ }^{148-151}$ The level and activity of soluble ACE2 in plasma seem to be increased in patients with heart failure. ${ }^{23,24,152}$ Associations between ACE2 polymorphisms and hypertrophic cardiomyopathy have also been reported. ${ }^{153,154}$

ACE2 shows multiple beneficial effects in left ventricular remodelling and dysfunction in rat models of cardiac hypertrophy induced by angiotensin II, diabetic cardiomyopathy induced by streptozotocin, and myocardial infarction induced by coronary artery occlusion. ${ }^{155-157}$ In mice with right ventricular dysfunction induced by pressure overload, treatment with recombinant human ACE2 reduces ventricular hypertrophy and improves systolic and diastolic functions. ${ }^{158}$ By contrast, Ace 2 knockout augments angiotensin-II-induced myocardial hypertrophy and interstitial fibrosis and accelerates the transition from hypertrophy to heart failure. ${ }^{159-162}$ Ace2 knockout also aggravates cardiac dysfunction induced by diabetes in mice. ${ }^{163}$ Although the cardioprotective mechanisms of ACE2 are not completely clear, mediation of 


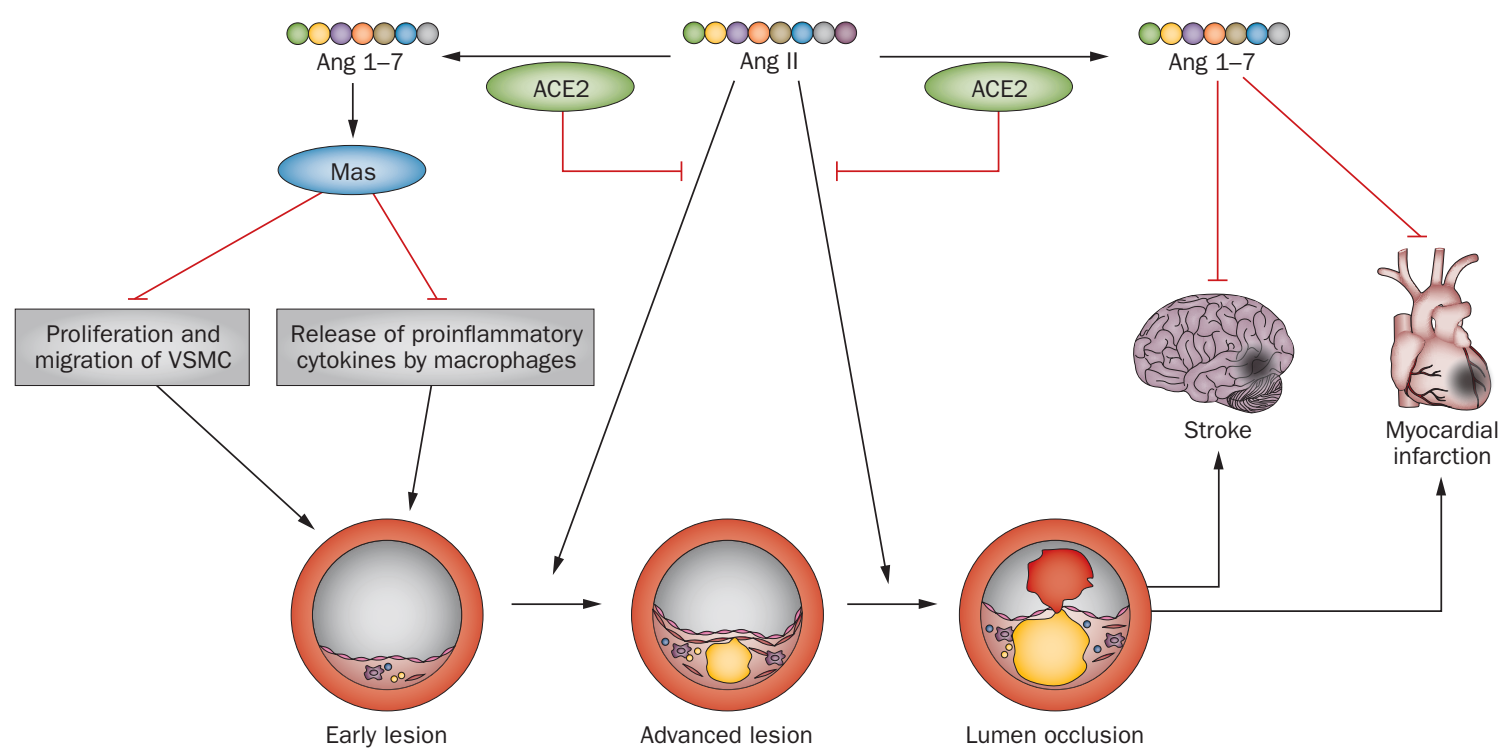

Figure 4 | Protective effects of ACE2 and Ang 1-7 on atherosclerosis and resultant myocardial infarction and stroke. Abbreviations: ACE2, angiotensin-converting enzyme 2; Ang, angiotensin; VSMC, vascular smooth muscle cell.

angiotensin II catabolism and subsequent inhibition of angiotensin-II-induced oxidative stress, inflammation, and interstitial fibrosis are thought to have important roles (Figure 5). ${ }^{156,160,163}$ In addition, reductions in sympathetic nerve activity might be attributable to ACE2induced cardioprotection, as demonstrated in studies with central ACE2 overexpression (Figure 5). ${ }^{164}$

Production of angiotensin 1-7 is substantially increased in heart failure induced by myocardial infarction. ${ }^{165}$ To date, most studies support that angiotensin 1-7 has protective effects on pathological cardiac remodelling and heart failure (Figure 5). For instance, systemic infusion of angiotensin 1-7 prevents the development of heart failure following myocardial infarction in rats. ${ }^{166}$ The angiotensin 1-7 receptor agonist AVE 0991 shows similar beneficial effects. ${ }^{167}$ Infusion of angiotensin 1-7 also prevents cardiac remodelling induced by angiotensin II in rats, ${ }^{168}$ and diabetes-induced diastolic dysfunction (with a preserved ejection fraction) in $\mathrm{db} / \mathrm{db}$ mice. ${ }^{169}$ Testis-specific angiotensin 1-7 in transgenic rats, which doubles the concentration of circulating angiotensin 1-7, has notable protective effects on myocardial hypertrophy and fibrosis induced by $\beta$-adrenoceptor agonists. ${ }^{170,171}$ Treatment with angiotensin 1-7 also produces equivalent protective actions on pressure-overload-induced cardiac hypertrophy and remodelling as AT1-receptor blockade in ACE2-null mice. ${ }^{172}$

The cardiac protective actions of angiotensin 1-7 are unlikely to be primarily mediated by a local mechanism in the myocardium, since the effects of cardiomyocyterestricted overexpression on pathological cardiac remodelling seem to be inconsistent. ${ }^{173,174,175}$ Additionally, the effects of angiotensin 1-7 on arrhythmia are biphasic; the beneficial effects on the myocardium associated with low concentrations arise through induction of hyperpolarization and increased the conduction velocity and refractoriness, whereas high concentrations have arrhythmogenic actions. ${ }^{50}$ Whether angiotensin 1-7 leads to cardiac dysfunction and remodelling in rodent models of renal disease is controversial. ${ }^{122,176}$

\section{Cerebral vessels and ischaemic stroke}

Involvement of angiotensin 1-7 in modulation of cerebral vascular functions and the process of ischaemic stroke (Figure 4) is supported by several studies. In ex vivo preparations of canine middle cerebral arteries, Feterik et al. ${ }^{177}$ demonstrated that angiotensin 1-7 induced endothelium-dependent relaxation sensitive to blockade of nitric oxide synthase and soluble guanylyl cyclase. Relaxation induced by angiotensin 1-7 is not affected by $\left(\mathrm{D}-\mathrm{Ala}^{7}\right)$-angiotensin-(1-7) or the AT2 receptor antagonist PD123319, but is partially blocked by a bradykinin B2 receptor antagonist. ${ }^{177}$ Similar vasodilatory effects have been observed in rat middle cerebral arteries. ${ }^{178}$ Moreover, chronic intravenous infusion of angiotensin 1-7 reversed endothelial dysfunction in the middle cerebral artery in rats maintained on a high-salt diet. ${ }^{178}$

In rats with acute ischaemic stroke, expression of ACE2 and Mas are upregulated, and concentrations of local and circulating angiotensin 1-7 are substantially increased. ${ }^{179}$ In a rat model of stroke, induced by occlusion of middle cerebral arteries, pretreatment with angiotensin $1-7$ by intracerebroventricular infusion was associated with reductions in infarct size and severity of neurological deficits; these effects were blocked by administration of $\left(\mathrm{D}-\mathrm{Ala}^{7}\right)$-angiotensin-(1-7). ${ }^{180,181}$ The neural protective actions of angiotensin 1-7 in brain ischaemia, however, are unlikely to be related to alterations in cerebral blood flow. Rather, they seem to be mediated by an antiinflammatory effect of angiotensin 1-7, as evidenced by reductions in the expression of inducible nitric oxide synthase and cyclo-oxygenase-2, activation of nuclear factor $\kappa \mathrm{B}$, oxidative stress, and release of proinflammatory cytokines in the injured brain tissue. ${ }^{180-182}$ 


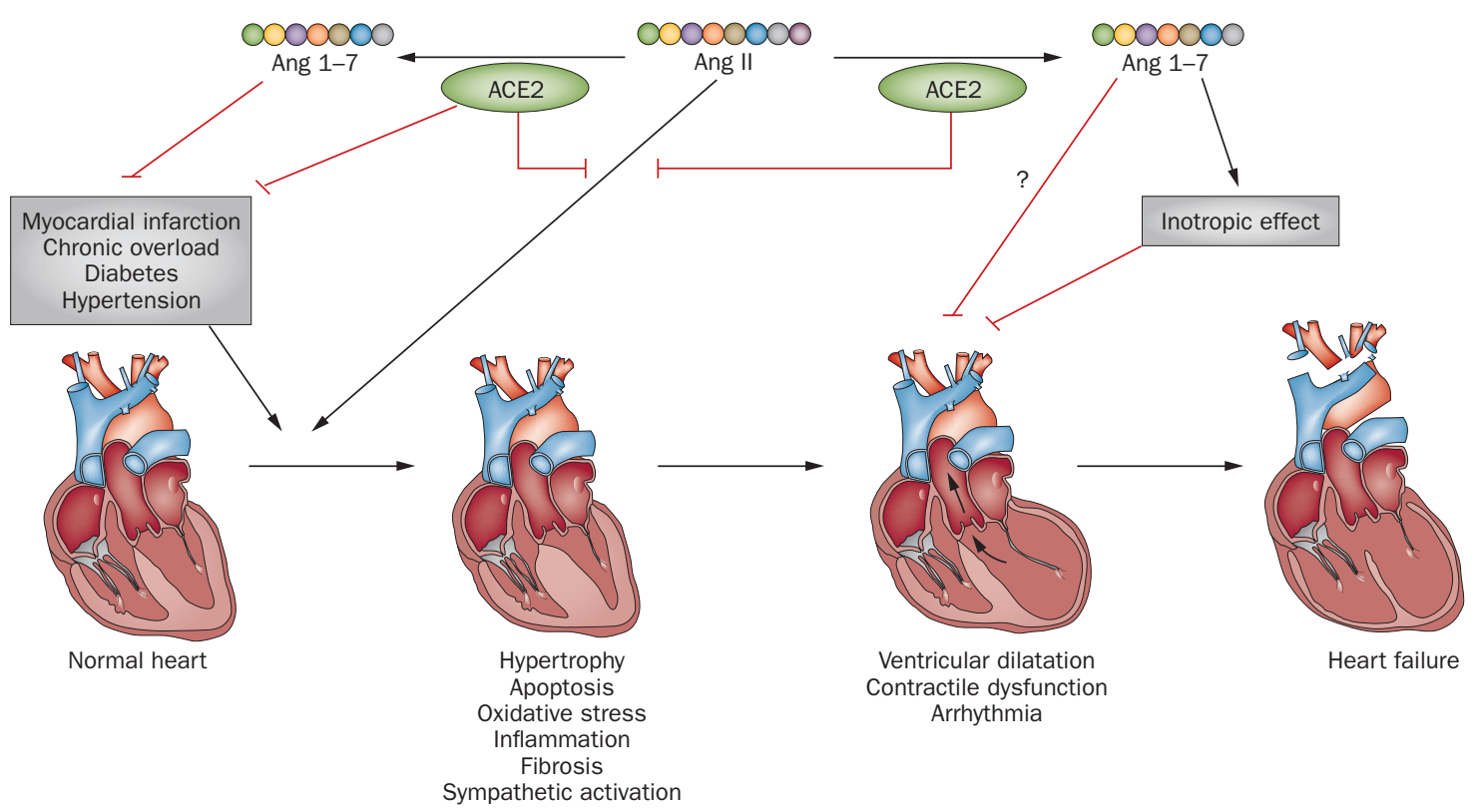

Figure 5 | Potential protective effects of ACE2 and Ang 1-7 on pathological cardiac remodelling and heart failure. Abbreviations: ACE2, angiotensin-converting enzyme 2; Ang, angiotensin.

\section{Diabetes}

Accumulating evidence has suggested that the functions of ACE2 and angiotensin 1-7 are affected by diabetes. Additionally, however, ACE2 and angiotensin 1-7 substantially affect glucose metabolism, which suggests they could have potential beneficial effects in patients with diabetes (Figure 6). Circulating ACE2 activity was increased in streptozotocin-treated rats with diabetes and in nonobese mice with diabetes. ${ }^{183,184}$ Likewise, ACE2 activity in serum was increased in humans with type 1 diabetes. ${ }^{185}$ Ectopic expression of human ACE2 in the pancreas of young $\mathrm{db} / \mathrm{db}$ mice was associated with significantly decreased hyperglycaemia, improved islet function, and reduced $\beta$-cell apoptosis. ${ }^{186}$ These effects were prevented by administration of $\left(\mathrm{D}-\mathrm{Ala}^{7}\right)$ angiotensin- $(1-7) .{ }^{186}$ Conversely, ACE2 deficiency aggravated impaired glucose tolerance and insulin sensitivity induced by diet. ${ }^{187}$ Increased circulating concentrations of angiotensin 1-7, as a result of chronic infusion or transgenic expression, ameliorated hyperinsulinaemia, insulin resistance, and inflammatory responses in adipose tissue in overnourished rats, ${ }^{45,188,189}$ and increased insulin sensitivity and glucose tolerance in normoglycaemic rats. ${ }^{47}$ Moreover, in a rat model of type 2 diabetes, chronic oral treatment with an angiotensin 1-7 formula induced a substantial hypoglycaemic effect, improved insulin sensitivity, and prevented hyperinsulinaemia. ${ }^{190}$

The mechanisms underlying the beneficial actions of ACE2 and angiotensin 1-7 in glucose metabolism could be multifaceted. First, activation of the RAS, especially the local RAS, for instance in skeletal muscle, adipose tissue, and the pancreas, contributes notably to the development of insulin resistance and diabetes. ${ }^{1,191}$ Hence, increased degradation of angiotensin II by ACE2 might be important in glucose metabolism. Second, angiotensin 1-7 can activate the phosphatidylinositol-3-kinase-Akt pathway ${ }^{45,51-55}$ and thereby facilitate insulin-induced signalling and glucose uptake. Angiotensin 1-7 might also antagonize dysfunction in insulin signalling induced by angiotensin II by preventing serine phosphorylation of insulin receptor substrate $1,{ }^{96}$ probably via inhibition of activation of MAPK pathways induced by angioten-

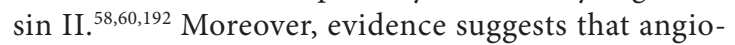
tensin 1-7 facilitates glucose uptake by upregulation of glucose transporter type 4 expression, which is the major glucose transporter in humans. ${ }^{187}$

ACE2 and angiotensin 1-7 have shown remarkable protective actions against diabetic nephropathy in several studies. Clinical and experimental studies have revealed reduced ACE2 expression in the kidney in the setting of diabetes and associated kidney disease. ${ }^{183,193-195}$ ACE2 inhibition with MLN-4760 worsened glomerular injury in mice with streptozotocin-induced diabetes, ${ }^{29}$ and Ace 2 knockout accelerated diabetes-induced kidney injuries. ${ }^{196,197}$ Increasing the ACE2 function in Akita mice with diabetes by systemic treatment with recombinant ACE2, however, ameliorated albuminuria and prevents glomerular proliferation, fibrosis, and oxidative stress. ${ }^{198}$ In rats with diabetes, global overexpression of ACE2 has produced remarkable renal protection similar to that induced by the ACE inhibitor benazepril, but no synergistic actions between ACE inhibition and ACE2 have been observed. ${ }^{199}$ Local overexpression of ACE2 in renal podocytes also seems to prevent kidney injuries in mice with diabetes. ${ }^{200}$ Additionally, chronic systemic treatment with angiotensin 1-7 reduced the risk of renal fibrosis, oxidative stress, and inflammation in the Zucker obese rat model of type 2 diabetes. ${ }^{201}$

\section{The gut}

ACE2 is highly expressed in gut tissues, at least in rodents. ${ }^{202}$ ACE2 in the gut has been shown to have a 


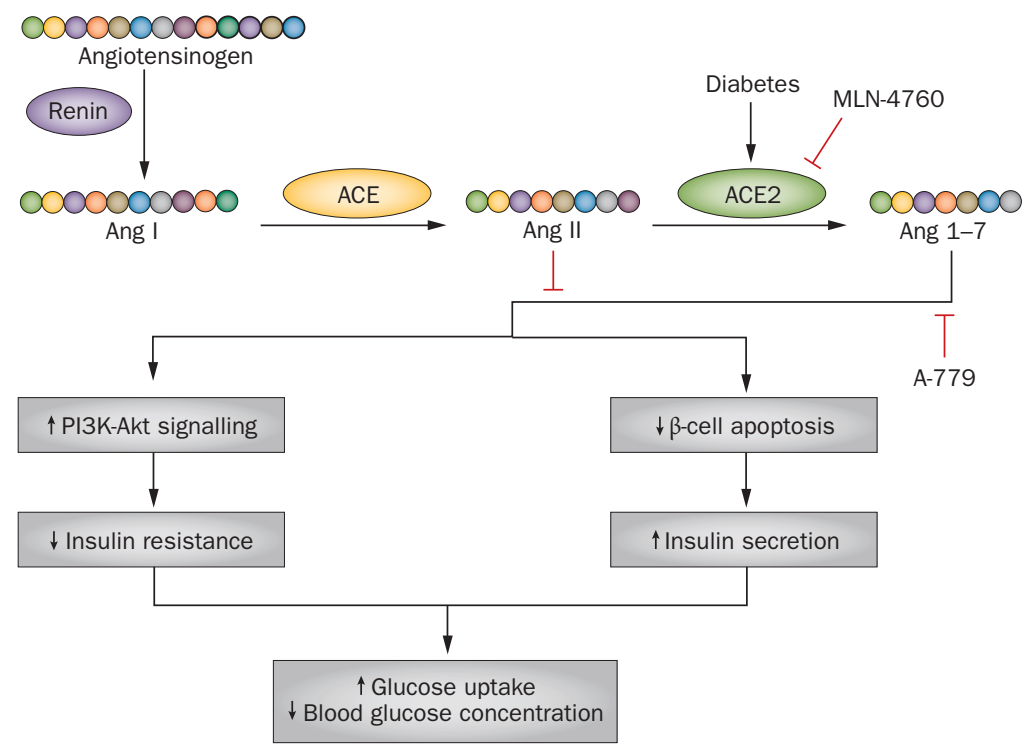

Figure 6 | Beneficial effects of ACE2 and Ang 1-7 on insulin resistance and diabetes. The conversion of Ang II to Ang 1-7 by ACE2 is increased in type 1 and in type 2 diabetes. Ang 1-7 increases insulin sensitivity and glucose uptake through activation of PI3K-Akt signalling and reduction of pancreatic $\beta$-cell apoptosis. Blockade of the effects of ACE2 by MLN-4760, or Ang 1-7 by A-779, might reverse the metabolic effects of ACE2 and Ang 1-7 and thereby worsen vascular complications. Abbreviations: ACE, angiotensin-converting enzyme; Ang, angiotensin; PI3K, phosphatidylinositol 3-kinase.

critical role in the regulation of intestinal innate immunity, amino acid homeostasis, and the ecology of the gut microbiota. ${ }^{203}$ ACE2 deficiency results in increased susceptibility to intestinal inflammation induced by epithelial damage. ${ }^{203}$ Of note, some evidence suggests that metabolism of dietary components by the intestinal microbiota might also have effects on the cardiovascular health ${ }^{204}$ which raises the possibility that ACE2 expressed in the gut contributes to vascular protection indirectly by modulating the interactions between gut microbiota and the intestinal epithelium.

\section{Targeted clinical therapies}

The success of chemical ACE inhibitors and AT1-receptor blockers in clinical management of various cardiovascular diseases underscores the possibility that searching for chemical modulators that target other active components of RAS could be fruitful. In a first-in-human study, human recombinant ACE2 was administered intravenously to healthy volunteers to assess the pharmacokinetic, pharmacodynamic, and safety profiles of native ACE2. ${ }^{205}$ Bioavailability of recombinant ACE2 in the human body showed a linear dose-dependent increase and had a terminal elimination half-life of $\sim 10 \mathrm{~h}$. Strikingly, within $30 \mathrm{~min}$ of administration of ACE2 at $400 \mu \mathrm{g} / \mathrm{kg}$ and $1,200 \mu \mathrm{g} / \mathrm{kg}$, the plasma concentration of angiotensin II dropped and remained suppressed for more than $24 \mathrm{~h}$. The level of angiotensin 1-7 varied in response to different doses of ACE2. Recombinant ACE2 was well tolerated, with no obvious effects on haemodynamic parameters. ${ }^{205}$ These results also highlight the possibility that, in humans, the potential cardiovascular protective actions of raised
ACE2 concentrations might largely be mediated by the accelerated catabolism of angiotensin II.

The basic pharmacokinetic and safety profiles of native angiotensin 1-7 were mainly obtained from several studies in patients with cancer. ${ }^{40,206}$ Native angiotensin 1-7 causes vasodilatation in healthy individuals and patients with hypertension, ${ }^{131}$ but it shows no effect in patients with heart failure. ${ }^{207}$ Angiotensin 1-7 is continuously catabolized by ACE, NEP, and aminopeptidases; therefore, decreased degradation seems to be a plausible contributor to the beneficial effects of ACE inhibitors. ${ }^{42}$ The value of angiotensin 1-7 as a therapeutic agent could be limited by the very short half-life of this peptide in the body. An ACE-resistant, cyclic angiotensin 1-7 analogue, in which a thioether bridge is introduced to the modified residues 4 and 7 of angiotensin 1-7, has been described. ${ }^{208}$ The bridged peptide was highly resistant to ACE activity, and showed a substantial (34-fold) reduction in plasma clearance in rats. Moreover, this agent induced a Masdependent vasodilator effect in isolated rat aorta. ${ }^{208}$ Thioether-bridged angiotensin 1-7 is stable at low (2.0) $\mathrm{pH}$ and is bioavailable after oral administration in rats. ${ }^{209}$ In a rat model of myocardial infarction, chronic infusion of thioether-bridged angiotensin 1-7 started 2 weeks after the infarction suppressed myocyte hypertrophy and improved cardiac and vascular functions. ${ }^{210}$

A hydroxypropyl $\beta$-cyclodextrin-incorporated angiotensin 1-7 formulation ( $\mathrm{HP} \beta \mathrm{CD} / \mathrm{Ang} 1-7)$ designed to overcome the instability of native angiotensin 1-7 in the gastrointestinal tract has been created. ${ }^{211}$ Oral treatment with $\mathrm{HP} \beta \mathrm{CD} /$ Ang1-7 has shown remarkable cardioprotective effects in rats with myocardial infarction and pathological remodelling after coronary artery occlusion. ${ }^{211,212}$ Moreover, orally administered HP $\beta C D /$ Ang1-7 was associated with improved lipid metabolism and prevention of hepatic steatosis in mice fed a high-fat diet. ${ }^{213}$ Similarly, long-term oral HP $\beta C D / A n g 1-7$ treatment was found to reverse established hyperglycaemia, improve insulin sensitivity, and prevent diabetic nephropathy in a transgenic rat model of insulin resistance and type 2 diabetes. ${ }^{190}$

Our understanding of the roles of ACE2 and angiotensin 1-7 is mainly derived from studies of experimental models. ${ }^{7,214-217}$ and evidence for biological actions in humans is sparse. Nevertheless, new drugs or pharmaceutical formulations targeting ACE2 and angiotensin 1-7 are expected to have strong clinical potential to treat cardiovascular diseases, especially those associated with increased activation of the conventional RAS. Research taking various directions, ${ }^{218}$ including modifications of native ACE2 and angiotensin 1-7 and identification of compounds that can specifically modulate the functions of ACE2, is underway. The latter might include small-molecule ACE2 activators and angiotensin 1-7 mimetics. Clearly, randomized, controlled clinical trials are required to assess the therapeutic efficacy and safety of targeted interventions.

\section{Conclusions}

Numerous experimental studies have suggested that ACE2 has protective effects in the heart and blood vessels, 
primarily by modulating the homeostasis of systemic neurohumoral factors and by improving cardiovascular risk factors. ACE2-mediated catabolism of angiotensin II is likely to have a major role in cardiovascular protection, especially in patients with overactive RAS. Interventions targeting ACE2, therefore, might represent a promising direction in the discovery of novel therapies for cardiovascular disease.

By contrast, the physiological and pharmacological actions of angiotensin 1-7 are complex and even paradoxical in certain circumstances, such as in the kidney. Similarly, the effects of angiotensin 1-7 on bloodpressure regulation are variable. Infusion of angiotensin 1-7 induces either vasodilatation or a null effect in normotensive humans. The effects of angiotensin 1-7 on cardiac dysfunction and remodelling caused by renal disease in rodents are contradictory in different studies. Moreover, angiotensin 1-7 shows biphasic actions on cardiac arrhythmia following myocardial injury. Therefore, more studies, especially controlled clinical trials, are needed to clearly delineate the benefits of angiotensin-1-7-based therapies.

Review criteria
The articles reviewed in this paper were selected from the
PubMed database using the search terms: “angiotensin-
converting enzyme 2 OR ACE2", or "angiotensin 1-7" or
"Mas", plus other identifiers, including (but not limited to)
"hypertension OR blood pressure", "atherosclerosis",
"heart OR cardiac remodeling", "diabetes OR insulin
resistance OR hyperinsulinaemia", and "stroke OR
cerebral vascular". Review articles were filtered by using
the search term "review [pt]". Articles relating to the
biochemistry and pharmacology of ACE2/angiotensin 1-7/
Mas were searched using terms including "biochemistry",
"inhibitor OR antagonist", "agonist OR activator", "binding
affinity", "ligand binding", or "pharmacokinetics OR
pharmacodynamics". On some occasions, terms including
"domain structure", "domains", or "crystallography" were
also used for a general search in the internet. We applied no
restrictions on date of publication or origin of the work, but
only articles published in English were included. Most of the
papers cited were full-text articles. Selected reference lists
from retrieved papers were used to identify further relevant
citations. During the revision stage we searched again to
update the reference list with the latest published articles.

1. Putnam, K., Shoemaker, R., Yiannikouris, F. \& Cassis, L. A. The renin-angiotensin system: a target of and contributor to dyslipidemias, altered glucose homeostasis, and hypertension of the metabolic syndrome. Am. J. Physiol. Heart Circ. Physiol. 302, H1219-H1230 (2012).

2. Lang, C. C. \& Struthers, A. D. Targeting the renin-angiotensin-aldosterone system in heart failure. Nat. Rev. Cardiol. 10, 125-134 (2013).

3. Nguyen Dinh Cat, A. \& Touyz, R. M. A new look at the renin-angiotensin system-focusing on the vascular system. Peptides 32, 2141-2150 (2011).

4. Hoogwerf, B. J. Renin-angiotensin system blockade and cardiovascular and renal protection. Am. J. Cardiol. 105, 30A-35A (2010).

5. Herichova, I. \& Szantoova, K. Renin-angiotensin system: upgrade of recent knowledge and perspectives. Endocr. Regul. 47, 39-52 (2013).

6. De Mello, W. C. \& Frohlich, E. D. On the local cardiac renin angiotensin system. Basic and clinical implications. Peptides 32, 1774-1779 (2011).

7. Bader, M. ACE2, angiotensin-(1-7), and Mas: the other side of the coin. Pflugers Arch. 465, 79-85 (2013).

8. Donoghue, M. et al. A novel angiotensinconverting enzyme-related carboxypeptidase (ACE2) converts angiotensin I to angiotensin 1-9 Circ. Res. 87, E1-E9 (2000).

9. Tipnis, S. R. et al. A human homolog of angiotensin-converting enzyme. Cloning and functional expression as a captoprilinsensitive carboxypeptidase. J. Biol. Chem. 275, 33238-33243 (2000).

10. Guang, C., Phillips, R. D., Jiang, B. \& Milani, F. Three key proteases-angiotensin---converting enzyme (ACE), ACE2 and renin — within and beyond the renin-angiotensin system. Arch. Cardiovasc. Dis. 105, 373-385 (2012).

11. Kuba, K., Imai, Y. \& Penninger, J. M. Multiple functions of angiotensin-converting enzyme 2 and its relevance in cardiovascular diseases. Circ. J. 77, 301-308 (2013).

12. Clarke, N. E. \& Turner, A. J. Angiotensinconverting enzyme 2: the first decade. Int. J. Hypertens. 2012, 307315 (2012).
13. Guy, J. L., Jackson, R. M., Jensen, H. A., Hooper, N. M. \& Turner, A. J. Identification of critical active-site residues in angiotensinconverting enzyme-2 (ACE2) by site-directed mutagenesis. FEBS J. 272, 3512-3520 (2005).

14. Zhang, $\mathrm{H}$. et al. Collectrin, a collecting ductspecific transmembrane glycoprotein, is a novel homolog of ACE2 and is developmentally regulated in embryonic kidneys. J. Biol. Chem. 276, 17132-17139 (2001).

15. Guy, J. L. et al. Angiotensin-converting enzyme-2 (ACE2): comparative modeling of the active site, specificity requirements, and chloride dependence. Biochemistry 42, 13185-13192 (2003).

16. Vickers, C. et al. Hydrolysis of biological peptides by human angiotensin-converting enzymerelated carboxypeptidase. J. Biol. Chem. 277, 14838-14843 (2002)

17. Ferrario, C. M., Trask, A. J. \& Jessup, J. A. Advances in biochemical and functional roles of angiotensin-converting enzyme 2 and angiotensin-(1-7) in regulation of cardiovascular function. Am. J. Physiol. Heart Circ. Physiol. 289, H2281-H2290 (2005).

18. Santos, R. A., Ferreira, A. J., Verano-Braga, T. \& Bader, M. Angiotensin-converting enzyme 2, angiotensin-(1-7) and Mas: new players of the renin-angiotensin system. J. Endocrinol. 216, R1-R17 (2013).

19. Flores-Munoz, M., Godinho, B. M., Almalik, A. \& Nicklin, S. A. Adenoviral delivery of angiotensin-(1-7) or angiotensin-(1-9) inhibits cardiomyocyte hypertrophy via the mas or angiotensin type 2 receptor. PLOS ONE 7 , e45564 (2012).

20. Flores-Munoz, M. et al. Angiotensin-(1-9) attenuates cardiac fibrosis in the strokeprone spontaneously hypertensive rat via the angiotensin type 2 receptor. Hypertension $\mathbf{5 9}$ 300-307 (2012).

21. Lambert, D. W. et al. Tumor necrosis factoralpha convertase (ADAM17) mediates regulated ectodomain shedding of the severe-acute respiratory syndrome-coronavirus (SARS-CoV) receptor, angiotensin-converting enzyme-2 (ACE2). J. Biol. Chem. 280, 30113-30119 (2005).
22. Imata, M., Silva Enciso, J. E. \& Greenberg, B. H. Selective and specific regulation of ectodomain shedding of angiotensin-converting enzyme 2 by tumor necrosis factor $\alpha$-converting enzyme. Am. J. Physiol. Cell Physiol. 297, C1318-C1329 (2009).

23. Epelman, S. et al. Detection of soluble angiotensin-converting enzyme 2 in heart failure: insights into the endogenous counter-regulatory pathway of the renin-angiotensin-aldosterone system. J. Am. Coll. Cardiol. 52, 750-754 (2008).

24. Epelman, S. et al. Soluble angiotensinconverting enzyme 2 in human heart failure: relation with myocardial function and clinical outcomes. J. Card Fail 15, 565-571 (2009).

25. Ortiz-Perez, J. T. et al. Role of circulating angiotensin converting enzyme 2 in left ventricular remodeling following myocardial infarction: a prospective controlled study. PLOS ONE 8 , e61695 (2013).

26. Patel, V. B. et al. Angiotensin II induced proteolytic cleavage of myocardial ACE2 is mediated by TACE/ADAM-17: a positive feedback mechanism in the RAS. J. Mol. Cell Cardiol. 66, 167-176 (2014).

27. Dales, N. A. et al. Substrate-based design of the first class of angiotensin-converting enzymerelated carboxypeptidase (ACE2) inhibitors. J. Am. Chem. Soc. 124, 11852-11853 (2002).

28. Towler, P. et al. ACE2 X-ray structures reveal a large hinge-bending motion important for inhibitor binding and catalysis. J. Biol. Chem. 279, 17996-18007 (2004).

29. Soler, M. J. et al. ACE2 inhibition worsens glomerular injury in association with increased ACE expression in streptozotocin-induced diabetic mice. Kidney Int. 72, 614-623 (2007).

30. Trask, A. J. et al. Inhibition of angiotensinconverting enzyme 2 exacerbates cardiac hypertrophy and fibrosis in Ren-2 hypertensive rats. Am. J. Hypertens. 23, 687-693 (2010).

31. Huang, L. et al. Novel peptide inhibitors of angiotensin-converting enzyme 2. J. Biol. Chem. 278, 15532-15540 (2003).

32. Uhal, B. D., Li, X., Xue, A., Gao, X. \& Abdul-Hafez, A. Regulation of alveolar epithelial cell survival by the ACE-2/angiotensin 1-7/Mas axis. Am. J. Physiol. Lung Cell. Mol. Physiol. 301, L269-L274 (2011). 
33. Fraga-Silva, R. A. et al. ACE2 activation promotes antithrombotic activity. Mol. Med. 16, 210-215 (2010).

34. Pedersen, K. B., Sriramula, S., Chhabra, K. H., Xia, H. \& Lazartigues, E. Species-specific inhibitor sensitivity of angiotensin-converting enzyme 2 (ACE2) and its implication for ACE2 activity assays. Am. J. Physiol. Regul. Integr. Comp. Physiol. 301, R1293-R1299 (2011).

35. Ye, M. et al. Murine recombinant angiotensinconverting enzyme 2: effect on angiotensin IIdependent hypertension and distinctive angiotensin-converting enzyme 2 inhibitor characteristics on rodent and human angiotensin-converting enzyme 2. Hypertension 60, 730-740 (2012).

36. Hernández Prada, J. A. et al. Structure-based identification of small-molecule angiotensinconverting enzyme 2 activators as novel antihypertensive agents. Hypertension 51 1312-1317 (2008).

37. Ferreira, A. J. et al. Angiotensin-converting enzyme 2 activation protects against hypertension-induced cardiac fibrosis involving extracellular signal-regulated kinases. Exp. Physiol. 96, 287-294 (2011).

38. Haber, P. K. et al. Angiotensin-converting enzyme 2-independent action of presumed angiotensin-converting enzyme 2 activators: studies in vivo, ex vivo, and in vitro. Hypertension 63, 774-782 (2014).

39. Campbell, D. J., Zeitz, C. J., Esler, M. D. \& Horowitz, J. D. Evidence against a major role for angiotensin converting enzyme-related carboxypeptidase (ACE2) in angiotensin peptide metabolism in the human coronary circulation. J. Hypertens. 22, 1971-1976 (2004).

40. Petty, W. J. et al. Phase I and pharmacokinetic study of angiotensin-(1-7), an endogenous antiangiogenic hormone. Clin. Cancer Res. 15, 7398-7404 (2009).

41. Yamada, K., Iyer, S. N., Chappell, M. C., Ganten, D. \& Ferrario, C. M. Converting enzyme determines plasma clearance of angiotensin-(1-7). Hypertension 32, 496-502 (1998)

42. Allred, A. J., Diz, D. I., Ferrario, C. M. \& Chappell, M. C. Pathways for angiotensin-(1-7) metabolism in pulmonary and renal tissues. Am. J. Physiol. Renal Physiol. 279, F841-F850 (2000).

43. Iusuf, D., Henning, R. H., van Gilst, W. H. \& Roks, A. J. Angiotensin-(1-7): pharmacological properties and pharmacotherapeutic perspectives. Eur. J. Pharmacol. 585, 303-312 (2008)

44. Zimmerman, D. \& Burns, K. D. Angiotensin-(1-7) in kidney disease: a review of the controversies. Clin. Sci. (Lond.) 123, 333-346 (2012).

45. Giani, J. F. et al. Chronic infusion of angiotensin-(1-7) improves insulin resistance and hypertension induced by a high-fructose diet in rats. Am. J. Physiol. Endocrinol. Metab. 296, E262-E271 (2009).

46. Echeverria-Rodriguez, O., Del Valle-Mondragon, L. \& Hong, E. Angiotensin 1-7 improves insulin sensitivity by increasing skeletal muscle glucose uptake in vivo. Peptides 51, 26-30 (2014).

47. Santos, S. H. et al. Improved lipid and glucose metabolism in transgenic rats with increased circulating angiotensin-(1-7). Arterioscler. Thromb. Vasc. Biol. 30, 953-961 (2010).

48. Donoghue, M. et al. Heart block, ventricular tachycardia, and sudden death in ACE2 transgenic mice with downregulated connexins. J. Mol. Cell Cardiol. 35, 1043-1053 (2003).

49. Neves, L. A., Almeida, A. P., Khosla, M. C., Campagnole-Santos, M. J. \& Santos, R. A. Effect of angiotensin-(1-7) on reperfusion arrhythmias in isolated rat hearts. Braz. J. Med. Biol. Res. 30, 801-809 (1997).

50. De Mello, W. C., Ferrario, C. M. \& Jessup, J. A. Beneficial versus harmful effects of angiotensin (1-7) on impulse propagation and cardiac arrhythmias in the failing heart. J. Renin Angiotensin Aldosterone Syst. 8, 74-80 (2007).

51. Dias-Peixoto, M. F. et al. Molecular mechanisms involved in the angiotensin-(1-7)/Mas signaling pathway in cardiomyocytes. Hypertension 52, 542-548 (2008).

52. Giani, J. F. et al. Angiotensin-(1 7) stimulates the phosphorylation of JAK2, IRS-1 and Akt in rat heart in vivo: role of the AT1 and Mas receptors. Am. J. Physiol. Heart Circ. Physiol. 293, H1154-H1163 (2007).

53. Sampaio, W. O. et al. Angiotensin-(1-7) through receptor Mas mediates endothelial nitric oxide synthase activation via Akt-dependent pathways. Hypertension 49, 185-192 (2007).

54. Than, A., Leow, M. K. \& Chen, P. Control of adipogenesis by the autocrine interplays between angiotensin 1-7/Mas receptor and angiotensin II/AT1 receptor signaling pathways. J. Biol. Chem. 288, 15520-15531 (2013).

55. Munoz, M. C., Giani, J. F. \& Dominici, F. P. Angiotensin-(1-7) stimulates the phosphorylation of Akt in rat extracardiac tissues in vivo via receptor Mas. Regul. Pept. 161, 1-7 (2010).

56. Sampaio, W. O., Henrique de Castro, C., Santos, R. A., Schiffrin, E. L. \& Touyz, R. M. Angiotensin-(1-7) counterregulates angiotensin II signaling in human endothelial cells. Hypertension 50, 1093-1098 (2007).

57. Tallant, E. A. \& Clark, M. A. Molecular mechanisms of inhibition of vascular growth by angiotensin-(1-7). Hypertension 42, 574-579 (2003).

58. Zhang, F., Hu, Y., Xu, Q. \& Ye, S. Different effects of angiotensin II and angiotensin-(1-7) on vascular smooth muscle cell proliferation and migration. PLoS ONE 5, e12323 (2010).

59. Tallant, E. A., Ferrario, C. M. \& Gallagher, P. E. Angiotensin-(1-7) inhibits growth of cardiac myocytes through activation of the mas receptor. Am. J. Physiol. Heart Circ. Physiol. 289 H1560-H1566 (2005).

60. Su, Z., Zimpelmann, J. \& Burns, K. D. Angiotensin-(1-7) inhibits angiotensin IIstimulated phosphorylation of MAP kinases in proximal tubular cells. Kidney Int. 69, 2212-2218 (2006).

61. Nie, W. et al. Angiotensin-(1-7) enhances angiotensin II induced phosphorylation of ERK1/2 in mouse bone marrow-derived dendritic cells. Mol. Immunol. 46, 355-361 (2009).

62. Zimpelmann, J. \& Burns, K. D. Angiotensin-(1-7) activates growth-stimulatory pathways in human mesangial cells. Am. J. Physiol. Renal Physiol. 296, F337-F346 (2009).

63. Liu, G. C., Oudit, G. Y., Fang, F., Zhou, J. \& Scholey, J. W. Angiotensin-(1-7)-induced activation of ERK1/2 is cAMP/protein kinase A-dependent in glomerular mesangial cells. Am. J. Physiol. Renal Physiol. 302, F784-F790 (2012).

64. De Mello, W. C. Angiotensin (1-7) increases the potassium current and the resting potential of arterial myocytes from vascular resistance vessels of normal adult rats: pathophysiological implications. J. Am. Soc. Hypertens. 8, 14-20 (2014).

65. Rowe, B. P., Saylor, D. L., Speth, R. C. \& Absher, D. R. Angiotensin-(1-7) binding at angiotensin II receptors in the rat brain. Regul. Pept. 56, 139-146 (1995).
66. Gironacci, M. M., Coba, M. P. \& Pena, C. Angiotensin-(1-7) binds at the type 1 angiotensin II receptors in rat renal cortex. Regul. Pept. 84, 51-54 (1999).

67. Bosnyak, S. et al. Relative affinity of angiotensin peptides and novel ligands at AT1 and AT2 receptors. Clin. Sci. (Lond.) 121, 297-303 (2011).

68. Lara Lda, S. et al. Involvement of the $\mathrm{G}_{\mathrm{i} / \mathrm{o}} / \mathrm{cGMP} /$ PKG pathway in the $\mathrm{AT}_{2}$-mediated inhibition of outer cortex proximal tubule $\mathrm{Na}^{+}$-ATPase by Ang-(1-7). Biochem. J. 395, 183-190 (2006).

69. Walters, P. E., Gaspari, T. A. \& Widdop, R. E. Angiotensin-(1-7) acts as a vasodepressor agent via angiotensin II type 2 receptors in conscious rats. Hypertension 45, 960-966 (2005).

70. Young, D., Waitches, G., Birchmeier, C., Fasano, O. $\&$ Wigler, M. Isolation and characterization of a new cellular oncogene encoding a protein with multiple potential transmembrane domains. Cell 45, 711-719 (1986)

71. Santos, R. A. et al. Angiotensin-(1-7) is an endogenous ligand for the $\mathrm{G}$ protein-coupled receptor Mas. Proc. Natl Acad. Sci. USA 100 8258-8263 (2003).

72. Metzger, R. et al. Expression of the mouse and rat mas proto-oncogene in the brain and peripheral tissues. FEBS Lett. 357, 27-32 (1995).

73. Alenina, N., Xu, P., Rentzsch, B., Patkin, E. L. \& Bader, M. Genetically altered animal models for Mas and angiotensin-(1-7). Exp. Physiol. 93, 528-537 (2008).

74. Young, D., O'Neill, K., Jessell, T. \& Wigler, M. Characterization of the rat mas oncogene and its high-level expression in the hippocampus and cerebral cortex of rat brain. Proc. Natl Acad. Sci. USA 85, 5339-5342 (1988).

75. Santos, R. A. et al. Impairment of in vitro and in vivo heart function in angiotensin-(1-7) receptor MAS knockout mice. Hypertension 47, 996-1002 (2006).

76. Tan, Z., Wu, J. \& Ma, H. Regulation of angiotensin-converting enzyme 2 and Mas receptor by Ang-(1-7) in heart and kidney of spontaneously hypertensive rats. J. Renin Angiotensin Aldosterone Syst. 12, 413-419 (2011).

77. Dias-Peixoto, M. F. et al. The cardiac expression of Mas receptor is responsive to different physiological and pathological stimuli. Peptides 35, 196-201 (2012)

78. Kumar, M., Grammas, P., Giacomelli, F. $\&$ Wiener, J. Selective expression of c-mas proto-oncogene in rat cerebral endothelial cells. Neuroreport 8, 93-96 (1996)

79. Muthalif, M. M., Benter, I. F., Uddin, M. R., Harper, J. L. \& Malik, K. U. Signal transduction mechanisms involved in angiotensin-(1-7)stimulated arachidonic acid release and prostanoid synthesis in rabbit aortic smooth muscle cells. J. Pharmacol. Exp. Ther. 284, 388-398 (1998).

80. Freeman, E. J., Chisolm, G. M., Ferrario, C. M. \& Tallant, E. A. Angiotensin-(1-7) inhibits vascular smooth muscle cell growth. Hypertension 28, 104-108 (1996)

81. Rabelo, L. A. et al. Ablation of angiotensin (1-7) receptor Mas in C57BI/ 6 mice causes endothelia dysfunction. J. Am. Soc. Hypertens. 2, 418-424 (2008).

82. Peiró, C. et al. Endothelial dysfunction through genetic deletion or inhibition of the G proteincoupled receptor Mas: a new target to improve endothelial function. J. Hypertens. 25, 2421-2425 (2007).

83. Pinheiro, S. V. et al. Genetic deletion of the angiotensin-(1-7) receptor Mas leads to 
glomerular hyperfiltration and microalbuminuria. Kidney Int. 75, 1184-1193 (2009).

84. Rakusan, D. et al. Knockout of angiotensin 1-7 receptor Mas worsens the course of two-kidney, one-clip Goldblatt hypertension: roles of nitric oxide deficiency and enhanced vascular responsiveness to angiotensin II. Kidney Blood Press Res. 33, 476-488 (2010).

85. Heringer-Walther, S. et al. The genetic deletion of Mas abolishes salt induced hypertension in mice. Eur. J. Pharmacol. 689, 147-153 (2012).

86. Xu, P., Sriramula, S. \& Lazartigues, E. ACE2/ ANG-(1-7)/Mas pathway in the brain: the axis of good. Am. J. Physiol. Regul. Integr. Comp. Physiol. 300, R804-R817 (2011).

87. Ferrario, C. M. \& Varagic, J. The ANG-(1-7)/ ACE2/mas axis in the regulation of nephron function. Am. J. Physiol. Renal Physiol. 298, F1297-F1305 (2010).

88. Iwai, M. \& Horiuchi, M. Devil and angel in the renin-angiotensin system: ACE-angiotensin II-AT1 receptor axis vs. ACE2-angiotensin-(1-7)-Mas receptor axis. Hypertens. Res. 32, 533-536 (2009).

89. Zohn, I. E., Symons, M., Chrzanowska-Wodnicka, M., Westwick, J. K. \& Der, C. J. Mas oncogene signaling and transformation require the small GTP-binding protein Rac. Mol. Cell Biol. 18, 1225-1235 (1998).

90. Gallagher, P. E. \& Tallant, E. A. Inhibition of human lung cancer cell growth by angiotensin-(1-7). Carcinogenesis 25, 2045-2052 (2004).

91. Krishnan, B., Torti, F. M., Gallagher, P. E. \& Tallant, E. A. Angiotensin-(1-7) reduces proliferation and angiogenesis of human prostate cancer xenografts with a decrease in angiogenic factors and an increase in sFlt-1. Prostate 73, 60-70 (2013).

92. Canals, M., Jenkins, L., Kellett, E. \& Milligan, G. Up-regulation of the angiotensin II type 1 receptor by the MAS proto-oncogene is due to constitutive activation of Gq/G11 by MAS. J. Biol. Chem. 281, 16757-16767 (2006).

93. Zhang, T. et al. Inhibition of Mas G-protein signaling improves coronary blood flow, reduces myocardial infarct size, and provides long-term cardioprotection. Am. J. Physiol. Heart Circ. Physiol. 302, H299-H311 (2012).

94. Chansel, D., Vandermeersch, S., Oko, A., Curat, C. \& Ardaillou, R. Effects of angiotensin IV and angiotensin-(1-7) on basal and angiotensin II-stimulated cytosolic $\mathrm{Ca}_{2}{ }^{+}$in mesangial cells. Eur. J. Pharmacol. 414, 165-175 (2001).

95. Ferrario, C. M. et al. Angiotensin-(1-7): a new hormone of the angiotensin system. Hypertension 18, III126-III133 (1991).

96. Tassone, E. J. et al. Angiotensin (1-7) counteracts the negative effect of angiotensin II on insulin signalling in HUVECs. Cardiovasc. Res. 99, 129-136 (2013).

97. Kostenis, E. et al. G.-protein-coupled receptor Mas is a physiological antagonist of the angiotensin II type 1 receptor. Circulation 111, 1806-1813 (2005).

98. Davenport, A. P. et al. International Union of Basic and Clinical Pharmacology. LXXXVIII. $G$ protein-coupled receptor list: recommendations for new pairings with cognate ligands. Pharmacol. Rev. 65, 967-986 (2013).

99. Santos, R. A. et al. Characterization of a new angiotensin antagonist selective for angiotensin-(1-7): evidence that the actions of angiotensin-(1-7) are mediated by specific angiotensin receptors. Brain Res. Bull. 35, 293-298 (1994).

100. Santos, R. A. et al. Characterization of a new selective antagonist for angiotensin-(1-7),
D-pro ${ }^{7}$-angiotensin-(1-7). Hypertension 41, 737-743 (2003).

101. Wiemer, G., Dobrucki, L. W., Louka, F. R., Malinski, T. \& Heitsch, H. AVE 0991, a nonpeptide mimic of the effects of angiotensin-(1-7) on the endothelium. Hypertension 40, 847-852 (2002).

102. Pinheiro, S. V. et al. Nonpeptide AVE 0991 is an angiotensin-(1-7) receptor Mas agonist in the mouse kidney. Hypertension 44, 490-496 (2004).

103. Savergnini, S. Q. et al. Vascular relaxation, antihypertensive effect, and cardioprotection of a novel peptide agonist of the MAS receptor. Hypertension 56, 112-120 (2010).

104. Gurley, S. B. et al. Altered blood pressure responses and normal cardiac phenotype in ACE2-null mice. J. Clin. Invest. 116, 2218-2225 (2006).

105. Yamazato, M., Yamazato, Y., Sun, C., Diez-Freire, C. \& Raizada, M. K. Overexpression of angiotensin-converting enzyme 2 in the rostral ventrolateral medulla causes long-term decrease in blood pressure in the spontaneously hypertensive rats. Hypertension 49, 926-931 (2007).

106. Sriramula, S., Cardinale, J. P., Lazartigues, E. \& Francis, J. ACE2 overexpression in the paraventricular nucleus attenuates angiotensin II-induced hypertension. Cardiovasc. Res. 92, 401-408 (2011).

107. Feng, Y. et al. Angiotensin-converting enzyme 2 overexpression in the subfornical organ prevents the angiotensin II-mediated pressor and drinking responses and is associated with angiotensin II type 1 receptor downregulation. Circ. Res. 102, 729-736 (2008).

108. Feng, Y. et al. Brain-selective overexpression of human Angiotensin-converting enzyme type 2 attenuates neurogenic hypertension. Circ. Res. 106, 373-382 (2010).

109. Rentzsch, B. et al. Transgenic angiotensinconverting enzyme 2 overexpression in vessels of SHRSP rats reduces blood pressure and improves endothelial function. Hypertension $\mathbf{5 2}$, 967-973 (2008).

110. Wysocki, J. et al. Targeting the degradation of angiotensin II with recombinant angiotensinconverting enzyme 2: prevention of angiotensin IIdependent hypertension. Hypertension $\mathbf{5 5}$, 90-98 (2010).

111. Lo, J. et al. Angiotensin-converting enzyme 2 antagonizes angiotensin II-induced pressor response and NADPH oxidase activation in Wistar-Kyoto rats and spontaneously hypertensive rats. Exp. Physiol. 98, 109-122 (2013).

112. Lima, C. V., Paula, R. D., Resende, F. L., Khosla, M. C. \& Santos, R. A. Potentiation of the hypotensive effect of bradykinin by short-term infusion of angiotensin-(1-7) in normotensive and hypertensive rats. Hypertension 30, 542-548 (1997).

113. Campagnole-Santos, M. J., Heringer, S. B., Batista, E. N., Khosla, M. C. \& Santos, R. A. Differential baroreceptor reflex modulation by centrally infused angiotensin peptides. Am. J. Physiol. 263, R89-R94 (1992).

114. Sampaio, W. O., Nascimento, A. A. \& Santos, R. A. Systemic and regional hemodynamic effects of angiotensin-(1-7) in rats. Am. J. Physiol. Heart Circ. Physiol. 284, H1985-H1994 (2003).

115. Bayorh, M. A. et al. 1A-779 attenuates angiotensin-(1-7) depressor response in saltinduced hypertensive rats. Peptides 23, 57-64 (2002).

116. Abbas, A., Gorelik, G., Carbini, L. A. \& Scicli, A. G. Angiotensin-(1-7) induces bradykinin-mediated hypotensive responses in anesthetized rats. Hypertension 30, 217-221 (1997).

117. Benter, I. F., Ferrario, C. M., Morris, M. \& Diz, D. I. Antihypertensive actions of angiotensin-(1-7) in spontaneously hypertensive rats. Am. J. Physiol. 269, H313-H319 (1995).

118. Eatman, D. et al. Gender differences in the attenuation of salt-induced hypertension by angiotensin (1-7). Peptides 22, 927-933 (2001).

119. Grobe, J. L., Mecca, A. P., Mao, H. \& Katovich, M. J. Chronic angiotensin-(1-7) prevents cardiac fibrosis in DOCA-salt model of hypertension. Am. J. Physiol. Heart Circ. Physiol. 290, H2417-H2423 (2006).

120. Burgelova, M. et al. Impairment of the angiotensin-converting enzyme 2-angiotensin(1-7)-Mas axis contributes to the acceleration of two-kidney, one-clip Goldblatt hypertension. J. Hypertens. 27, 1988-2000 (2009).

121. Shah, A., Oh, Y. B., Lee, S. H., Lim, J. M. \& Kim, S. H. Angiotensin-(1-7) attenuates hypertension in exercise-trained renal hypertensive rats. Am. J. Physiol. Heart Circ. Physiol. 302, H2372-H2380 (2012).

122. Velkoska, E., Dean, R. G., Griggs, K., Burchill, L. \& Burrell, L. M. Angiotensin-(1-7) infusion is associated with increased blood pressure and adverse cardiac remodelling in rats with subtotal nephrectomy. Clin. Sci. (Lond.) 120, 335-345 (2011).

123. Moriguchi, A., Ferrario, C. M., Brosnihan, K. B., Ganten, D. \& Morris, M. Differential regulation of central vasopressin in transgenic rats harboring the mouse Ren-2 gene. Am. J. Physiol. 267, R786-R791 (1994).

124. Guimaraes, P. S. et al. Chronic infusion of angiotensin-(1-7) into the lateral ventricle of the brain attenuates hypertension in DOCAsalt rats. Am. J. Physiol. Heart Circ. Physiol. 303, H393-H400 (2012).

125. Xue, B. et al. Central endogenous angiotensin(1-7) protects against aldosterone/ $\mathrm{NaCl}$ induced hypertension in female rats. Am. J. Physiol. Heart Circ. Physiol. 305, H699-H705 (2013).

126. Nakagaki, T. et al. Role of angiotensin-(1-7) in rostral ventrolateral medulla in blood pressure regulation via sympathetic nerve activity in Wistar-Kyoto and spontaneous hypertensive rats. Clin. Exp. Hypertens. 33, 223-230 (2011).

127. Oliveira, D. R., Santos, R. A., Santos, G. F., Khosla, M. \& Campagnole-Santos, M. J. Changes in the baroreflex control of heart rate produced by central infusion of selective angiotensin antagonists in hypertensive rats. Hypertension 27, 1284-1290 (1996).

128. Simoes e Silva, A. C., Bello, A. P., Baracho, N. C., Khosla, M. C. \& Santos, R. A. Diuresis and natriuresis produced by long term administration of a selective angiotensin-(1-7) antagonist in normotensive and hypertensive rats. Regul. Pept. 74, 177-184 (1998)

129. Britto, R. R., Santos, R. A., Fagundes-Moura, C. R. Khosla, M. C. \& Campagnole-Santos, M. J. Role of angiotensin-(1-7) in the modulation of the baroreflex in renovascular hypertensive rats. Hypertension 30, 549-556 (1997).

130. Iyer, S. N., Chappell, M. C., Averill, D. B., Diz, D. I. \& Ferrario, C. M. Vasodepressor actions of angiotensin-(1-7) unmasked during combined treatment with lisinopril and losartan. Hypertension 31, 699-705 (1998).

131. Sasaki, S. et al. Effects of angiotensin-(1-7) on forearm circulation in normotensive subjects and patients with essential hypertension. Hypertension 38, 90-94 (2001).

132. Plovsing, R. R. et al. Effects of truncated angiotensins in humans after double blockade 
of the renin system. Am. J. Physiol. Regul. Integr. Comp. Physiol. 285, R981-R991 (2003).

133. Zulli, A., Rai, S., Buxton, B. F., Burrell, L. M. $\&$ Hare, D. L. Co-localization of angiotensinconverting enzyme 2-, octomer-4- and CD34positive cells in rabbit atherosclerotic plaques. Exp. Physiol. 93, 564-569 (2008).

134. Purushothaman, K. R. et al. Expression of angiotensin-converting enzyme 2 and its end product angiotensin 1-7 is increased in diabetic atheroma: implications for inflammation and neovascularization. Cardiovasc. Pathol. 22, 42-48 (2013).

135. Sluimer, J. C. et al. Angiotensin-converting enzyme 2 (ACE2) expression and activity in human carotid atherosclerotic lesions. J. Pathol. 215, 273-279 (2008).

136. Wang, Y., Tikellis, C., Thomas, M. C. \& Golledge, J. Angiotensin converting enzyme 2 and atherosclerosis. Atherosclerosis 226, 3-8 (2013).

137. Lovren, F. et al. Angiotensin converting enzyme-2 confers endothelial protection and attenuates atherosclerosis. Am. J. Physiol. Heart Circ. Physiol. 295, H1377-H1384 (2008).

138. Zhang, C. et al. Angiotensin-converting enzyme 2 attenuates atherosclerotic lesions by targeting vascular cells. Proc. Natl Acad. Sci. USA 107 15886-15891 (2010).

139. Dong, B. et al. Overexpression of ACE2 enhances plaque stability in a rabbit model of atherosclerosis. Arterioscler. Thromb. Vasc. Biol. 28, 1270-1276 (2008).

140. Thomas, M. C. et al. Genetic Ace2 deficiency accentuates vascular inflammation and atherosclerosis in the $A p o E$ knockout mouse. Circ. Res. 107, 888-897 (2010).

141. Thatcher, S. E. et al. Angiotensin-converting enzyme 2 deficiency in whole body or bone marrow-derived cells increases atherosclerosis in low-density lipoprotein receptor $\%$ mice. Arterioscler. Thromb. Vasc. Biol. 31, 758-765 (2011)

142. Sahara, M. et al. Deletion of angiotensinconverting enzyme 2 promotes the development of atherosclerosis and arterial neointima formation. Cardiovasc. Res. 101, 236-246 (2014)

143. Tesanovic, S., Vinh, A., Gaspari, T. A., Casley, D. \& Widdop, R. E. Vasoprotective and atheroprotective effects of angiotensin (1-7) in apolipoprotein E-deficient mice. Arterioscler. Thromb. Vasc. Biol. 30, 1606-1613 (2010).

144. Yang, J. M. et al. Angiotensin-(1-7) dosedependently inhibits atherosclerotic lesion formation and enhances plaque stability by targeting vascular cells. Arterioscler. Thromb. Vasc. Biol. 33, 1978-1985 (2013).

145. Toton-Zuranska, J. et al. AVE 0991-angiotensin(1-7) receptor agonist, inhibits atherogenesis in apoE-knockout mice. J. Physiol. Pharmacol. 61, 181-183 (2010)

146. Jawien, J. et al. Angiotensin-(1-7) receptor Mas agonist ameliorates progress of atherosclerosis in apoE-knockout mice. J. Physiol. Pharmacol. 63, 77-85 (2012).

147. Zhang, F., Ren, J., Chan, K. \& Chen, H. Angiotensin-(1-7) regulates angiotensin IIinduced VCAM-1 expression on vascular endothelial cells. Biochem. Biophys. Res. Commun. 430, 642-646 (2013).

148. Goulter, A. B., Goddard, M. J., Allen, J. C. \& Clark, K. L. ACE2 gene expression is up regulated in the human failing heart. BMC Med. 2,19 (2004).

149. Ohtsuki, M. et al. Angiotensin converting enzyme 2 gene expression increased compensatory for left ventricular remodeling in patients with end-stage heart failure. Int. J. Cardiol. 145, 333-334 (2010).

150. Kittleson, M. M. et al. Gene expression analysis of ischemic and nonischemic cardiomyopathy: shared and distinct genes in the development of heart failure. Physiol. Genomics 21, 299-307 (2005).

151. Batlle, M. et al. Increased expression of the renin-angiotensin system and mast cell density but not of angiotensin-converting enzyme II in late stages of human heart failure. J. Heart Lung Transplant 25, 1117-1125 (2006).

152. Wang, Y. et al. Plasma ACE2 activity is an independent prognostic marker in Chagas' disease and equally potent as BNP. J. Card. Fail. 16, 157-163 (2010).

153. Lieb, W. et al. Association of angiotensinconverting enzyme 2 (ACE2) gene polymorphisms with parameters of left ventricular hypertrophy in men. Results of the MONICA Augsburg echocardiographic substudy. J. Mol. Med. (Berl.) 84, 88-96 (2006).

154. van der Merwe, L. et al. Genetic variation in angiotensin-converting enzyme 2 gene is associated with extent of left ventricular hypertrophy in hypertrophic cardiomyopathy. Hum. Genet. 124, 57-61 (2008).

155. Huentelman, M. J. et al. Protection from angiotensin I-induced cardiac hypertrophy and fibrosis by systemic lentiviral delivery of ACE2 in rats. Exp. Physiol. 90, 783-790 (2005)

156. Dong, B. et al. Angiotensin-converting enzyme-2 overexpression improves left ventricular remodeling and function in a rat model of diabetic cardiomyopathy. J. Am. Coll. Cardiol. 59 , 739-747 (2012).

157. Zhao, Y. X. et al. ACE2 overexpression ameliorates left ventricular remodeling and dysfunction in a rat model of myocardial infarction. Hum. Gene Ther. 21, 1545-1554 (2010).

158. Johnson, J. A., West, J., Maynard, K. B. \& Hemnes, A. R. ACE2 improves right ventricular function in a pressure overload model. PLOS ONE 6, e20828 (2011).

159. Oudit, G. Y. et al. Angiotensin II-mediated oxidative stress and inflammation mediate the age-dependent cardiomyopathy in ACE2 null mice. Cardiovasc. Res. 75, 29-39 (2007)

160. Zhong, J. et al. Angiotensin-converting enzyme 2 suppresses pathological hypertrophy, myocardial fibrosis, and cardiac dysfunction. Circulation 122, 717-728 (2010).

161. Bodiga, S. et al. Enhanced susceptibility to biomechanical stress in ACE2 null mice is prevented by loss of the p47(phox) NADPH oxidase subunit. Cardiovasc. Res. 91, 151-161 (2011).

162. Yamamoto, K. et al. Deletion of angiotensinconverting enzyme 2 accelerates pressure overload-induced cardiac dysfunction by increasing local angiotensin II. Hypertension 47, 718-726 (2006).

163. Patel, V. B. et al. Loss of angiotensin-converting enzyme-2 exacerbates diabetic cardiovascular complications and leads to systolic and vascular dysfunction: a critical role of the angiotensin II/ AT1 receptor axis. Circ. Res. 110, 1322-1335 (2012).

164. Feng, Y., Hans, C., Mcllwain, E., Varner, K. J. \& Lazartigues, E. Angiotensin-converting enzyme 2 over-expression in the central nervous system reduces angiotensin-II-mediated cardiac hypertrophy. PLoS ONE 7, e48910 (2012).

165. Averill, D. B., Ishiyama, Y., Chappell, M. C. \& Ferrario, C. M. Cardiac angiotensin-(1-7) in ischemic cardiomyopathy. Circulation 108 , 2141-2146 (2003)
166. Loot, A. E. et al. Angiotensin-(1-7) attenuates the development of heart failure after myocardial infarction in rats. Circulation 105, 1548-1550 (2002)

167. Ferreira, A. J. et al. The nonpeptide angiotensin-(1-7) receptor Mas agonist AVE-0991 attenuates heart failure induced by myocardial infarction. Am. J. Physiol. Heart Circ Physiol. 292, H1113-H1119 (2007).

168. Mori, J. et al. Angiotensin 1-7 ameliorates diabetic cardiomyopathy and diastolic dysfunction in $\mathrm{db} / \mathrm{db}$ mice by reducing lipotoxicity and inflammation. Circ. Heart Fail. 7, 327-339 (2014).

169. Grobe, J. L. et al. Prevention of angiotensin IIinduced cardiac remodeling by angiotensin-(1-7). Am. J. Physiol. Heart Circ. Physiol. 292, H736-H742 (2007)

170. Santos, R. A. et al. Expression of an angiotensin-(1-7)-producing fusion protein produces cardioprotective effects in rats. Physiol. Genomics 17, 292-299 (2004).

171. Nadu, A. P., Ferreira, A. J., Reudelhuber, T. L. Bader, M. \& Santos, R. A. Reduced isoproterenolinduced renin-angiotensin changes and extracellular matrix deposition in hearts of TGR(A1-7)3292 rats. J. Am. Soc. Hypertens. 2 341-348 (2008)

172. Patel, V. B. et al. Cardioprotective effects mediated by angiotensin II type 1 receptor blockade and enhancing angiotensin 1-7 in experimental heart failure in angiotensinconverting enzyme 2-null mice. Hypertension 59, 1195-1203 (2012)

173. Wang, Y. et al. Circulating rather than cardiac angiotensin-(1-7) stimulates cardioprotection after myocardial infarction. Circ. Heart Fail. 3, 286-293 (2010).

174. Mercure, C. et al. Angiotensin(1-7) blunts hypertensive cardiac remodeling by a direct effect on the heart. Circ. Res. 103, 1319-1326 (2008)

175. Ferreira, A. J. et al. Attenuation of isoproterenolinduced cardiac fibrosis in transgenic rats harboring an angiotensin-(1-7)-producing fusion protein in the heart. Ther. Adv. Cardiovasc. Dis. 4 83-96 (2010).

176. Li, Y. et al. Angiotensin (1-7) prevent heart dysfunction and left ventricular remodeling caused by renal dysfunction in 5/6 nephrectomy mice. Hypertens. Res. 32, 369-374 (2009).

177. Feterik, K., Smith, L. \& Katusic, Z. S. Angiotensin-(1-7) causes endotheliumdependent relaxation in canine middle cerebral artery. Brain Res. 873, 75-82 (2000).

178. Durand, M. J., Raffai, G., Weinberg, B. D. \& Lombard, J. H. Angiotensin-(1-7) and low-dose angiotensin II infusion reverse salt-induced endothelial dysfunction via different mechanisms in rat middle cerebral arteries. Am. J. Physiol. Heart Circ. Physiol. 299, H1024-H1033 (2010).

179. Lu, J. et al. The expression of angiotensinconverting enzyme 2-angiotensin-(1-7)-Mas receptor axis are upregulated after acute cerebral ischemic stroke in rats. Neuropeptides 47, 289-295 (2013).

180. Mecca, A. P. et al. Cerebroprotection by angiotensin-(1-7) in endothelin-1-induced ischaemic stroke. Exp. Physiol. 96, 1084-1096 (2011)

181. Jiang, T. et al. Suppressing inflammation by inhibiting the NF-kappaB pathway contributes to the neuroprotective effect of angiotensin-(1-7) in rats with permanent cerebral ischaemia. $\mathrm{Br}$. J. Pharmacol. 167, 1520-1532 (2012).

182. Regenhardt, R. W. et al. Anti-inflammatory effects of angiotensin-(1-7) in ischemic stroke. Neuropharmacology 71, 154-163 (2013). 
183. Yamaleyeva, L. M. et al. Differential regulation of circulating and renal ACE2 and ACE in hypertensive mRen2.Lewis rats with early-onset diabetes. Am. J. Physiol. Renal Physiol. 302, F1374-F1384 (2010).

184. Riera, M. et al. Effect of insulin on ACE2 activity and kidney function in the non-obese diabetic mouse. PLoS ONE 9, e84683 (2014).

185. Soro-Paavonen, A. et al. Circulating ACE2 activity is increased in patients with type 1 diabetes and vascular complications. J. Hypertens. 30, 375-383 (2012).

186. Bindom, S. M., Hans, C. P., Xia, H., Boulares, A. H. \& Lazartigues, E. Angiotensin I-converting enzyme type 2 (ACE2) gene therapy improves glycemic control in diabetic mice. Diabetes 59 2540-2548 (2010)

187. Takeda, M. et al. Loss of ACE2 exaggerates high-calorie diet-induced insulin resistance by reduction of GLUT4 in mice. Diabetes 62 , 223-233 (2013).

188. Marcus, Y. et al. Angiotensin 1-7 as means to prevent the metabolic syndrome: lessons from the fructose-fed rat model. Diabetes 62, 1121-1130 (2013).

189. Santos, S. H. et al. Increased circulating angiotensin-(1-7) protects white adipose tissue against development of a proinflammatory state stimulated by a high-fat diet. Regul. Pept. 178, 64-70 (2012).

190. Santos, S. H. et al. Oral administration of angiotensin-(1-7) ameliorates type 2 diabetes in rats. J. Mol. Med. (Berl.) 92, 255-265 (2014).

191. Underwood, P. C. \& Adler, G. K. The renin angiotensin aldosterone system and insulin resistance in humans. Curr. Hypertens. Rep. 15, 59-70 (2013).

192. Andreozzi, F., Laratta, E., Sciacqua, A., Perticone, F. \& Sesti, G. Angiotensin II impairs the insulin signaling pathway promoting production of nitric oxide by inducing phosphorylation of insulin receptor substrate-1 on Ser312 and Ser616 in human umbilical vein endothelial cells. Circ. Res. 94, 1211-1218 (2004).

193. Reich, H. N., Oudit, G. Y., Penninger, J. M., Scholey, J. W. \& Herzenberg, A. M. Decreased glomerular and tubular expression of ACE2 in patients with type 2 diabetes and kidney disease. Kidney Int. 74, 1610-1616 (2008).

194. Ye, M. et al. Glomerular localization and expression of angiotensin-converting enzyme 2 and angiotensin-converting enzyme: implications for albuminuria in diabetes. J. Am. Soc. Nephrol. 17, 3067-3075 (2006).

195. Mizuiri, S. et al. Expression of ACE and ACE2 in individuals with diabetic kidney disease and healthy controls. Am. J. Kidney Dis. 51, 613-623 (2008).
196. Wong, D. W. et al. Loss of angiotensin-converting enzyme-2 (Ace2) accelerates diabetic kidney injury. Am. J. Pathol. 171, 438-451 (2007).

197. Shiota, A. et al. Loss of ACE2 accelerates timedependent glomerular and tubulointerstitial damage in streptozotocin-induced diabetic mice. Hypertens. Res. 33, 298-307 (2010).

198. Oudit, G. Y. et al. Human recombinant ACE2 reduces the progression of diabetic nephropathy. Diabetes 59, 529-538 (2010).

199. Liu, C. X. et al. Angiotensin-converting enzyme (ACE) 2 overexpression ameliorates glomerular injury in a rat model of diabetic nephropathy: a comparison with ACE inhibition. Mol. Med. 17 , 59-69 (2011)

200. Nadarajah, R. et al. Podocyte-specific overexpression of human angiotensin-converting enzyme 2 attenuates diabetic nephropathy in mice. Kidney Int. 82, 292-303 (2012).

201. Giani, J. F. et al. Angiotensin-(1-7) attenuates diabetic nephropathy in Zucker diabetic fatty rats. Am. J. Physiol. Renal Physiol. 302, F1606-F1615 (2012).

202. Gembardt, F. et al. Organ-specific distribution of ACE2 mRNA and correlating peptidase activity in rodents. Peptides 26, 1270-1277 (2005).

203. Hashimoto, T. et al. ACE2 links amino acid malnutrition to microbial ecology and intestinal inflammation. Nature 487, 477-481 (2012).

204. Wang, Z. et al. Gut flora metabolism of phosphatidylcholine promotes cardiovascular disease. Nature 472, 57-63 (2011).

205. Haschke, M. et al. Pharmacokinetics and pharmacodynamics of recombinant human angiotensin-converting enzyme 2 in healthy human subjects. Clin. Pharmacokinet 52, 783-792 (2013).

206. Rodgers, K. E., Oliver, J. \& diZerega, G. S Phase I/II dose escalation study of angiotensin 1-7 [A(1-7)] administered before and after chemotherapy in patients with newly diagnosed breast cancer. Cancer Chemother. Pharmacol. 57, 559-568 (2006).

207. Davie, A. P. \& McMurray, J. J. Effect of angiotensin-(1-7) and bradykinin in patients with heart failure treated with an ACE inhibitor. Hypertension 34, 457-460 (1999).

208. Kluskens, L. D. et al. Angiotensin-(1-7) with thioether bridge: an angiotensin-converting enzyme-resistant, potent angiotensin-(1-7) analog. J. Pharmacol. Exp. Ther. 328, 849-854 (2009).

209. de Vries, L. et al. Oral and pulmonary delivery of thioether-bridged angiotensin-(1-7). Peptides 31, 893-898 (2010).

210. Durik, M. et al. The effect of the thioether-bridged, stabilized angiotensin-(1-7) analogue cyclic ang-(1-7) on cardiac remodeling and endothelial function in rats with myocardial infarction. Int. J. Hypertens. 2012, 536426 (2012).

211. Marques, F. D. et al. An oral formulation of angiotensin-(1-7) produces cardioprotective effects in infarcted and isoproterenol-treated rats. Hypertension 57, 477-483 (2011).

212. Marques, F. D. et al. Beneficial effects of longterm administration of an oral formulation of angiotensin-(1-7) in infarcted rats. Int. J. Hypertens. 2012, 795452 (2012).

213. Feltenberger, J. D. et al. Oral formulation of angiotensin-(1-7) improves lipid metabolism and prevents high-fat diet-induced hepatic steatosis and inflammation in mice. Hypertension 62, 324-330 (2013).

214. Passos-Silva, D. G., Verano-Braga, T. \& Santos, R. A. Angiotensin-(1-7): beyond the cardio-renal actions. Clin. Sci. (Lond.) 124, 443-456 (2013).

215. Rabelo, L. A., Alenina, N. \& Bader, M. ACE2-angiotensin-(1-7)-Mas axis and oxidative stress in cardiovascular disease. Hypertens. Res. 34, 154-160 (2011).

216. Simoes e Silva, A. C., Silveira, K. D., Ferreira, A. J. \& Teixeira, M. M. ACE2, angiotensin-(1-7) and Mas receptor axis in inflammation and fibrosis. Br. J. Pharmacol. 169, 477-492 (2013).

217. Xia, H. \& Lazartigues, E. Angiotensin-converting enzyme 2: central regulator for cardiovascular function. Curr. Hypertens. Rep. 12, 170-175 (2010).

218. Ferreira, A. J., Bader, M. \& Santos, R. A. Therapeutic targeting of the angiotensinconverting enzyme 2/angiotensin-(1-7)/Mas cascade in the renin-angiotensin system: a patent review. Expert Opin. Ther. Pat. 22, 567-574 (2012).

\section{Acknowledgements}

The authors are supported by research grants from National 973 Basic Research Program (No. 2010CB732605, 2011CB503906, 2012CB518603, 2013CB530703), National Hightech Research and Development Program of China (No. 2012AA02A510), Program of Introducing Talents of Discipline to Universities (No. B07035), the State Program of National Natural Science Foundation of China for Innovative Research Group (No. 81321061), International Collaboration and Exchange Program of China (No. 81320108004) and the State Key Program of National Natural Science of China (No. 61331001).

\section{Author contributions}

All authors participated in literature research and data classification. F.J., J.Y., and C.Z. wrote the manuscript. F.J. and C.Z. reviewed and/or edited the manuscript before submission. F.J., M.D, S.W., Q.Z. and F.F.L. contributed to the creation of artworks. 